\title{
Infanticide as Sexual Conflict: Coevolution of Male Strategies and Female Counterstrategies
}

\author{
Ryne A. Palombit \\ Department of Anthropology, Center for Human Evolutionary Studies, Rutgers University, \\ New Brunswick, New Jersey 08901 \\ Correspondence: rpalombit@anthropology.rutgers.edu
}

\begin{abstract}
One of the earliest recognized forms of sexual conflict was infanticide by males, which imposes serious costs on female reproductive success. Here I review two bodies of evidence addressing coevolved strategies of males and females. The original sexual selection hypothesis arguing that infanticide improves male mating success by accelerating the return of females to fertilizable condition has been generally supported in some taxa-notably, some primates, carnivores, rodents, and cetaceans-but not in other taxa. One result of recent research has been to implicate other selective benefits of infanticide by males in various taxa from insects to birds to mammals, such as acquisition of breeding status or improvement of the female breeding condition. In some cases, however, the adaptive significance of male infanticide remains obscure. The second body of data I review is arguably the most important result of recent research: clarifying the possible female counterstrategies to infanticide. These potential counterstrategies span diverse biological systems, ranging from sexual behavior (e.g., polyandrous mating), to physiology (e.g., the Bruce effect), to individual behavior (e.g., maternal aggression), to social strategies (e.g., association with coalitionary defenders of either sex). Although much remains to be studied, these current data provide compelling evidence of sexually antagonistic coevolution surrounding the phenomenon of infanticide.
\end{abstract}

\begin{abstract}
$A^{t}$ its most elemental level, infanticide is the Akilling of a newborn individual by a conspecific. With the growing appreciation of its biological significance, however, infanticide came to be defined more broadly as any "behavior that makes a direct and significant contribution to the immediate death of an embryo or newly hatched or born member of the performer's own species" (Mock 1984, p. 4) or "any form of lethal curtailment of parental investment in offspring brought about by conspecifics" (Hrdy
\end{abstract}

and Hausfater 1984, p. xv). These definitions highlight the heterogeneous and variable nature of the phenomenon, which can be perpetrated by either sex, by parents or other kin, by individuals unrelated to the victim, in a wide variety of social and mating systems, under a range of seasonal or aseasonal breeding regimes, and across diverse taxa straddling vertebrates and invertebrates.

One adaptive form of infanticide-the killing of infants by unrelated males-is arguably

Editors: William R. Rice and Sergey Gavrilets

Additional Perspectives on The Genetics and Biology of Sexual Conflict available at www.cshperspectives.org

Copyright (C) 2015 Cold Spring Harbor Laboratory Press; all rights reserved; doi: 10.1101/cshperspect.a017640

Cite this article as Cold Spring Harb Perspect Biol 2015;7:a017640 
R.A. Palombit

the archetype of sexual conflict. In 450 BCE, Herodotus not only documented the behavior among Egyptian cats, but explained it as a male "trick" to obtain sexual access to females otherwise preoccupied with maternal duties (Delibes et al. 2012). Among the myriad ideas inaugurating sociobiology in the 1970s, the hypothesis that infanticide is a male strategy that improves reproductive success at the expense of female fitness (Hrdy 1974) constituted one of the first demonstrations of the "battle of the sexes" theory developed by Williams (1966) and Trivers (1972). Partly because of the controversy surrounding the appearance of this hypothesis (Rees 2009), however, subsequent research focused more on male strategy than on the other party in this sexual dialectic, the female. Thus, field and laboratory research has helped to establish its many forms and conditional occurrence, describe its distribution across taxa, and clarify its adaptive significance, but it is only relatively recently that female counterstrategies have become the subjects of rigorous study, even though their potential importance was grasped early on (Hrdy 1979).

In this article, I review selected aspects of this body of data and analysis. My focus is on nonparental male infanticide targeting dependent young - in mammals, nursing individuals - as opposed to older, weaned offspring, the killing of which is variably rendered "juvenilicide," "pedicide," or "filicide" (e.g., Agoramoorthy and Mohnot 1988; Palombit 2014, in press).

\section{THE SEXUAL CONFLICT OF INFANTICIDE: MALE STRATEGIES}

Several functional hypotheses have been proposed to explain male infanticide. Foremost among them historically is the sexual selection hypothesis. I consider this hypothesis first, with special, although not exclusive, taxonomic focus on the group of animals that originally generated the hypothesis-the primates. I then move on to several alternative hypotheses for male infanticide, the discussion of which will incorporate consideration of data from other animals as well as additional data from primates.

\section{Sexual Selection Hypothesis}

Although male infanticide clearly has no unitary explanation, the biological relevance of intrasexual selection in males makes the sexual selection hypothesis a good starting point for discussion. As originally formulated for langurs (Semnopithecus entellus), Hrdy's (1974, 1977) argument is that the killing of an infant prematurely ends lactational amenorrhea (the cessation of ovulatory cycles during nursing) in its mother, thereby significantly advancing the time when she is available for subsequent fertilization by the perpetrator. The potential benefit of this strategy to male fitness will depend on many variables, but salient among them is the degree to which sexual access to fecund females is limited by two factors: male-male competition and the reproductive life history of females.

The latter of these factors provides a useful context for analyzing the problem of male infanticide. The $\mathrm{L} / \mathrm{G}$ ratio, which compares the durations of lactation and gestation, summarizes the potential value (to males) and vulnerability (to females) of infanticide in mammals. When lactation greatly exceeds gestation, postpartum mating and early pregnancy impose potentially prohibitive costs on females in the form of simultaneous support of two sets of offspring differing in ages, requirements, and competitive capacities (van Schaik 2000b). The adaptive solution to this female problem is lactational amenorrhea, which, however, generates the reproductive problem for males that infanticide can solve. Plainly expressed: An infant is a "perfect contraceptive," and infanticide simply serves to remove this effect (Altmann et al. 1978, p. 1029).

The taxonomic distribution of sexually selected infanticide across mammals is not fully resolved, but current reports of infanticide whose patterning is consistent with this hypothesis are predictably concentrated among taxa with relatively long L/G ratios - namely, primates, fissiped carnivores, and odontocete 
whales (Fig. 1) (van Schaik 2000b). Several caveats warrant mention. First, this result does not mean that male infanticide is uniformly expressed within these taxa; on the contrary, there is often considerable variation over time and across populations (see below). Second, it is also not the case that male infanticide is unreported in other taxa with lower L/G ratios, but in those cases the sexually selected mechanism has been less implicated than alternative hypotheses (see below). Finally, L/G ratios are important, but other factors may explain the rarity of infanticide in some mammals, for example, ecologically determined sexual segregation, (Kunz and Ebensperger 1999), caching of infants as an antipredator strategy (Schülke 2005), need for hibernation (Thalmann 2001), or even phylogenetic inertia (Ebensperger 2001).

It is not possible here to review comprehensively the empirical tests of the sexual selection hypothesis (see Hausfater and Hrdy 1984; Parmigiani et al. 1994; Connor et al. 2000; van
Schaik and Janson 2000; Ebensperger and Blumstein 2007; Palombit 2012), but some general patterns can be highlighted. The largest body of data supporting this hypothesis has come from study of the nonhuman primates. In the last 25 years, the number of species in which infanticide had been observed directly or inferred from substantive indirect evidence in the wild has risen from a dozen (HiraiwaHasegawa 1988) to 54, including 84 distinct populations distributed across nine of the 14 families of strepsirrhines, monkeys, and apes (updated from Palombit 2012).

The circumstances surrounding infanticide in primates are typically (although not invariably) consistent with the sexual selection hypothesis: (1) replacement of a male occupying the position of sole or dominant breeder in the group by a male who is unlikely to have sired the infants he subsequently attacks; (2) resumption of ovulatory cycling by the mother; and (3) copulation between the mother and perpetra-

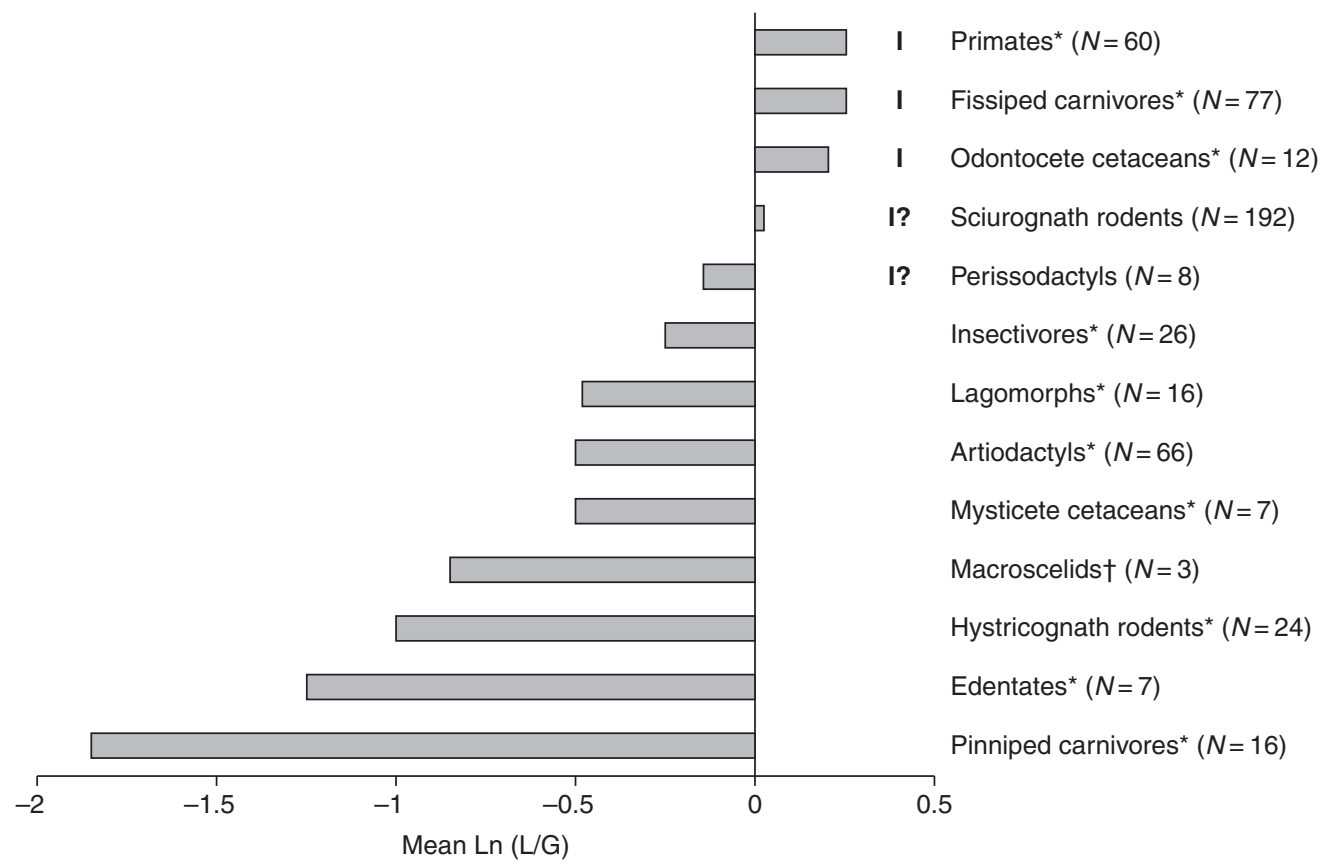

Figure 1. Mean lactation/gestation $(\mathrm{L} / \mathrm{G})$ ratios for selected mammalian groups. Log-transformed L/G ratios significantly different from 1 are indicted by $*(p<0.05)$ or $\dagger(p<0.01)$. The letter "I" denotes taxa in which deliberate sexually selected infanticide by males has been recorded. Sample sizes (number of species) are indicated in parentheses. (Modified from data in van Schaik 2000b.) 
R.A. Palombit

tor, and thus shortening of the interbirth interval. Most but not all reports provide supportive data for all three predictions, but cases in which behavioral data are unavailable or contradictory more often concern the third prediction. Advances in field methodology have permitted collection of ancillary (nonbehavioral) data to further test the hypothesis. For example, DNA data establish that males are unrelated to the infants they attack (Pereira and Weiss 1991; Borries et al. 1999a; Soltis et al. 2000) or are fathers of the female's next infant (Morelli et al. 2009), whereas hormonal data provide direct evidence of maternal resumption of ovulatory cycling following infanticide (Harris and Monfort 2003) as well as elevated stress response in mothers following heightened infanticide risk or actual attacks (Beehner et al. 2005; see also Brockman et al. 2009). Thus, as a general explanation of infanticide, the sexual selection hypotheses has received more support than alternative hypotheses (see below) (van Schaik 2000a; Palombit 2012).

Although originally observed for primates living in unimale, polygynous groups, male infanticide has been observed in almost all of the other social systems found in this order, from dispersed societies, to multimale groups, to fission-fusion communities, and perhaps even socially monogamous pairs. Its occurrence in some multimale societies is noteworthy. The permanent presence of multiple males was expected to hinder infanticide by increasing its costs (through male defense of infants) or decreasing its potential benefits (through reduced ability to monopolize matings). Thus, across gregarious primates, infanticide rate is negatively correlated with the number of males in groups (Janson and van Schaik 2000). Nevertheless, significant male infanticide has been documented in a number of multimale societies in two general contexts: (1) by new immigrants (or, somewhat less commonly, by long-term residents) that rise to the alpha position in the male dominance hierarchy (e.g., Palombit et al. 2000; Soltis et al. 2000; Teichroeb and Sicotte 2008); or (2) by coalitionary cohorts of alien males that collectively replace the entire male membership of a group (Fedigan et al. 2008) in a manner reminiscent of lions (Pusey and Packer 1994b). One factor apparently promoting infanticide in this social context is pronounced mating skew toward dominant males (sensu Broom et al. 2004).

Compelling evidence for sexually selected infanticide in the nonprimate mammals has come from field studies of fissiped carnivores (particularly bears and well-studied lions); there are also some suggestive recent data for toothed whales (particularly dolphins) (Table 1). Among rodents, the altriciality of young and lengthy periods of female investment make sexually selected infanticide likely in many species, particularly in the murids (Wolff and MacDonald 2004). Male infanticide is known in 14-17 species of Muridae (Ebensperger and Blumstein 2007). The Norway rat (Rattus norvegicus), house mouse (Mus musculus/domesticus), and Mongolian gerbil (Meriones unguiculatus) have been the subjects of extensive and well-controlled laboratory research (see references in Table 1), which has shed important light on the proximate mechanisms underlying infanticide and on female counterstrategies. These data for murids are largely consistent with the sexual selection hypothesis, but almost all of them come from the laboratory; only four murid species have provided limited data on male infanticide in the wild (see Caley and Boutin 1985; Wolff and Cicirello 1991; Ylönen et al. 1997). It is partly because "virtually nothing is known" about infanticide in natural populations of murids (Berdoy and Drickamer 2007, p. 389) that the broader implications of the laboratory results are debated, particularly vis-à-vis the predicted postinfanticide reproductive benefits. Thus, Ebensperger and Blumstein (2007, p. 178) conclude that although current data reject nonadaptive explanations, the sexual selection hypothesis "remains unproven in rodents" (see also below for sciurid rodents).

Alternative Explanations for Male Infanticide

Besides the sexual selection hypothesis, there is a large number of alternative adaptive explanations for male infanticide (Table 1). Only a few of these can be addressed here. It is perhaps 
Table 1. Adaptive and nonadaptive hypotheses for nonparental infanticide by males

\begin{tabular}{|c|c|c|}
\hline Hypothesis & Theoretical rationale & Proposed example taxa \\
\hline \multicolumn{3}{|c|}{ Benefits related to mating } \\
\hline $\begin{array}{l}\text { Sexual selection } \\
\text { I. Accelerate female } \\
\text { return to breeding } \\
\text { condition }\end{array}$ & $\begin{array}{l}\text { When sexual access to } \\
\text { fecund females is limited } \\
\text { by intrasexual } \\
\text { competition, killing eggs } \\
\text { or infants accelerates } \\
\text { female return to } \\
\text { fertilizable condition } \\
\text { (mammals: shortens } \\
\text { lactational amenorrhea) } \\
\text { for subsequent } \\
\text { insemination }\end{array}$ & $\begin{array}{l}\text { Arachnids; birds (Hirundo } \\
\text { rustica, Passer domesticus); } \\
\text { hippos (Hippopotamus } \\
\text { amphibius); horses (Equus } \\
\text { caballus); dolphins } \\
\text { (Tursiops spp.); lions } \\
\text { (Panthera leo); bears (Ursus } \\
\text { arctos); murid rodents } \\
\text { (M. musculus, } \\
\text { R. norvegicus, Peromyscus } \\
\text { spp., M. unguiculatus, } \\
\text { Myodes glareolus); tree } \\
\text { squirrels (Paraxerus } \\
\text { cepapi); relatively many } \\
\text { primate species }\end{array}$ \\
\hline
\end{tabular}

\section{Improved female Premature termination of condition and future fertility \\ lactational amenorrhea improves female condition and thereby enhances future reproductive success following insemination by infanticidal male}

Breeding site acquisition acquisition

Breeding site
acquisition
Direct Infanticide facilitates acquisition of high rank or breeding status in multimale groups for resident males or new immigrants

Infanticide is part of a strategy to take over a breeding site by destroying existing offspring, and then mating with the resident female(s) or new immigrant female(s)
Crook and Shields 1985; Veiga 1993; Pusey and Packer 1994b; Schneider and Lubin 1997; Lewinson 1998; Patterson et al. 1998; Swenson et al. 2001; Dunn et al. 2002; Erez et al. 2005; McLellan 2005; Bellemain et al. 2006a; Solomon and Keane 2007; Dudzinski et al. 2009; Gray 2009; Zedrosser et al. 2009; see references in Ebensperger and Blumstein 2007 and Palombit 2012

Arctic ground squirrels (Spermophilus parryii); red deer (Cervus elaphus); horses (E. caballus, E. ferus przewalskii); ring-tailed lemurs (Lemur catta); sifakas (Propithecus edwardsi)

Howler monkeys (Alouatta arctoides); baboons (Papio hamadryas hamadryas); Hanuman langurs (S. entellus)

Burying beetles (Nicrophorus spp.); fish (Lamprologus callipterus); birds (Tachycineta bicolor, Troglodytes aedon)

McLean 1983; Bartoš and Madlafousek 1994; Wright 1995; Jolly et al. 2000; Cameron et al. 2003; Hoesli et al. 2009; Morelli et al. 2009

Angst and Thommen 1977; Crockett 2003; Rajpurohit et al. 2008

Freed 1986, 1987; Robertson and Stutchbury 1988; Trumbo 1990a; Trumbo and Valletta 2007; Maan and Taborsky 2008

Crook and Shields 1985; Watts 1989; Steenbeek 2000; Møller 2004; Korstjens et al. 2005 
R.A. Palombit

Table 1. Continued

\begin{tabular}{|c|c|c|c|}
\hline Hypothesis & Theoretical rationale & Proposed example taxa & References \\
\hline Indirect & $\begin{array}{l}\text { In species with female } \\
\text { dispersal, infanticide by } \\
\text { an extragroup male } \\
\text { disrupts the mother- } \\
\text { subadult daughter bond, } \\
\text { facilitating the dispersal } \\
\text { of latter to infanticidal } \\
\text { male }\end{array}$ & $\begin{array}{l}\text { Chimpanzees (Pan } \\
\text { troglodytes) }\end{array}$ & Goodall 1986 \\
\hline $\begin{array}{l}\text { Sexual } \\
\text { monopolization } \\
\text { of female }\end{array}$ & $\begin{array}{l}\text { Infanticide induces female } \\
\text { to restrict future } \\
\text { copulations to } \\
\text { infanticidal males(s) than } \\
\text { to other male(s) }\end{array}$ & Chimpanzees (P. troglodytes) & Hamai et al. 1992 \\
\hline $\begin{array}{l}\text { Removal of mating } \\
\text { competitors }\end{array}$ & $\begin{array}{l}\text { Selective killing of male } \\
\text { infants: (a) eliminates } \\
\text { possible future sexual } \\
\text { competitors of } \\
\text { infanticidal males or their } \\
\text { sons; (b) undermines } \\
\text { coalitionary power of } \\
\text { rival males? }\end{array}$ & $\begin{array}{l}\text { Arctic ground squirrels } \\
\text { (S. parryii); Hanuman } \\
\text { langurs (S. entellus); white- } \\
\text { thighed colobus monkeys } \\
\text { (Colobus vellerosus) }\end{array}$ & $\begin{array}{l}\text { McLean 1983; Sommer } \\
\text { 1994; Teichroeb and } \\
\text { Sicotte } 2008\end{array}$ \\
\hline $\begin{array}{l}\text { Decrease } \\
\text { reproductive } \\
\text { success of rivals }\end{array}$ & $\begin{array}{l}\text { Infanticide removes genes of } \\
\text { rival male(s) }\end{array}$ & $\begin{array}{l}\text { Tree squirrel (P. cepapi); fur } \\
\text { seals (Callorhinus ursinus); } \\
\text { patas monkey } \\
\text { (Erythrocebus patas) }\end{array}$ & $\begin{array}{l}\text { de Villiers 1986; Enstam } \\
\text { et al. 2002; Kiyota and } \\
\text { Okamura } 2005\end{array}$ \\
\hline \multicolumn{4}{|c|}{ Benefits related to resources } \\
\hline $\begin{array}{l}\text { Removal of } \\
\text { competitors for } \\
\text { limiting resources }\end{array}$ & $\begin{array}{l}\text { Infanticide improves access } \\
\text { to limiting food resources } \\
\text { to infanticidal male and/ } \\
\text { or his offspring }\end{array}$ & $\begin{array}{l}\text { Gerbils (M. unguiculatus); } \\
\text { purple-faced langurs } \\
\text { (Semnopithecus vetulus); } \\
\text { howler monkeys (Alouatta } \\
\text { arctoides, A. palliata) }\end{array}$ & $\begin{array}{l}\text { Rudran 1973b; Clarke } \\
\text { 1983; Elwood and } \\
\text { Ostermeyer 1984b; } \\
\text { Agoramoorthy and } \\
\text { Rudran } 1995\end{array}$ \\
\hline $\begin{array}{l}\text { Improved intergroup } \\
\text { competition for } \\
\text { limited resources }\end{array}$ & $\begin{array}{l}\text { Killing of infants in } \\
\text { neighboring groups } \\
\text { enhances access to } \\
\text { resources by: (a) causing } \\
\text { their mothers to } \\
\text { withdraw permanently } \\
\text { from borders areas, } \\
\text { thereby facilitating } \\
\text { killers' home range to } \\
\text { expand; (b) facilitating } \\
\text { intergroup dominance } \\
\text { and thereby priority of } \\
\text { access of resources in } \\
\text { border areas }\end{array}$ & $\begin{array}{l}\text { (a) Chimpanzees } \\
\text { (P. troglodytes); (b) guereza } \\
\text { (Colobus guereza) }\end{array}$ & $\begin{array}{l}\text { (a) Watts et al. 2002; } \\
\text { Williams et al. 2002, } \\
\text { 2004; Mitani et al. 2010; } \\
\text { (b) Harris and Monfort } \\
2003\end{array}$ \\
\hline $\begin{array}{l}\text { Nutritional } \\
\text { exploitation }\end{array}$ & $\begin{array}{l}\text { Infants are cannibalized to } \\
\text { obtain direct nutritional } \\
\text { benefits }\end{array}$ & $\begin{array}{l}\text { Fish (Telmatherina } \\
\text { sarasinorum); yellow } \\
\text { sciurid rodents } \\
\text { (Spermophilus beldingi, }\end{array}$ & $\begin{array}{l}\text { Paul and Kupferschmidt } \\
\text { 1975; Svare and Bartke } \\
\text { 1978; Sherman 1981; } \\
\text { Elwood and }\end{array}$ \\
\hline
\end{tabular}

Continued 
Table 1. Continued

\begin{tabular}{|c|c|c|c|}
\hline Hypothesis & Theoretical rationale & Proposed example taxa & References \\
\hline & & $\begin{array}{l}\text { S. tridecemlineatus, } \\
\text { Cynomys parvidens); murid } \\
\text { rodents (R. norvegicus, } \\
\text { M. musculus, } \\
\text { M. unguiculatus, Microtus } \\
\text { pennsylvanicus); baboons } \\
\text { (Papio cynocephalus) }\end{array}$ & $\begin{array}{l}\text { Ostermeyer 1984a; } \\
\text { Vestal 1991; } \\
\text { Ebensperger et al. 2000; } \\
\text { Hoogland 2001; } \\
\text { Altmann et al. 2006; } \\
\text { Gray et al. } 2007\end{array}$ \\
\hline \multicolumn{4}{|c|}{ Benefits related to paternal investment } \\
\hline $\begin{array}{l}\text { Avoidance of } \\
\quad \text { misdirected } \\
\text { paternal } \\
\text { investment }\end{array}$ & $\begin{array}{l}\text { Infanticide prevents male } \\
\text { parental investment in } \\
\text { offspring sired by another } \\
\text { male }\end{array}$ & $\begin{array}{l}\text { Birds (T. aedon, } P \text {. domesticus); } \\
\text { humans (Homo sapiens) }\end{array}$ & $\begin{array}{l}\text { Daly and Wilson 1984, } \\
\text { 1994; Rohwer 1986; } \\
\text { Freed 1987; Pierotti } \\
\text { 1991; Veiga } 1993\end{array}$ \\
\hline \multicolumn{4}{|c|}{ Benefits related to learning } \\
\hline $\begin{array}{l}\text { Acquisition of } \\
\text { mating tactics and } \\
\text { skills }\end{array}$ & $\begin{array}{l}\text { Inexperienced subadult } \\
\text { males lethally use pups as } \\
\text { proxies for adult females } \\
\text { to acquire skill in mating } \\
\text { tactics (e.g., female } \\
\text { stealing and herding, } \\
\text { territory maintenance) }\end{array}$ & $\begin{array}{l}\text { Otariid seals (Mirounga spp., } \\
\text { Callorhinus ursinus) }\end{array}$ & $\begin{array}{l}\text { Le Boeuf and Campagna } \\
\text { 1994; Kiyota and } \\
\text { Okamura } 2005\end{array}$ \\
\hline \multicolumn{4}{|c|}{ Nonadaptive hypotheses } \\
\hline Social pathology & $\begin{array}{l}\text { Lethal attacks on infants are: } \\
\text { (a) abnormal behavior } \\
\text { resulting from human- } \\
\text { induced disturbance } \\
\text { (e.g., overcrowding) or } \\
\text { selection; (b) results of } \\
\text { changes in nature/rate of } \\
\text { aggression (e.g., takeover, } \\
\text { intergroup hostility) } \\
\text { caused by anthropogenic } \\
\text { disturbance and habitat } \\
\text { degradation }\end{array}$ & $\begin{array}{l}\text { Horses (E. ferus przewalskii); } \\
\text { episodic in others (e.g., } \\
\text { Hanuman langurs) } \\
\text { (S. entellus); Tibetan } \\
\text { macaques (Macaca } \\
\text { thibetana); chimpanzees } \\
\text { (P. troglodytes) }\end{array}$ & $\begin{array}{l}\text { Jansen et al. 2002; (a) } \\
\text { Dolhinow 1977; Curtin } \\
\text { and Dolhinow 1978; } \\
\text { Feh and Munkhtuya } \\
\text { 2008; (b) Boggess 1984; } \\
\text { Berman et al. 2007; } \\
\text { Williams et al. } 2008\end{array}$ \\
\hline $\begin{array}{l}\text { Generalized } \\
\text { aggression }\end{array}$ & $\begin{array}{l}\text { Infant killing is an } \\
\text { incidental byproduct of } \\
\text { selection for overall intra- } \\
\text { or intersexual } \\
\text { aggressiveness in males or } \\
\text { (for intergroup } \\
\text { infanticide) of general } \\
\text { male xenophobic } \\
\text { territoriality }\end{array}$ & $\begin{array}{l}\text { Otariid seals (Mirounga spp., } \\
\text { Otaria byronia); horses } \\
\text { (E. ferus przewalskii); } \\
\text { episodic in others (e.g., } \\
\text { baboons) (Papio } \\
\text { h. hamadryas); macaques } \\
\text { (Macaca radiata); mona } \\
\text { monkey (Cercopithecus } \\
\text { campbellii); chimpanzees } \\
\text { (P. troglodytes) }\end{array}$ & $\begin{array}{l}\text { Galat-Luong and Galat } \\
\text { 1979; Rijksen 1981; } \\
\text { Goodall 1990; Bartlett } \\
\text { et al. 1993; Le Boeuf } \\
\text { and Campagna 1994; } \\
\text { Singh et al. 2006; Hoesli } \\
\text { et al. } 2009\end{array}$ \\
\hline
\end{tabular}


unsurprising that the two taxa in Figure 1 that ostensibly straddle the "high $\mathrm{L} / \mathrm{G}$ " and "low $\mathrm{L} / \mathrm{G}$ " groupings have generated conflicting results and debate about sexually selected infanticide. These are the sciurid rodents and the perissodactyls.

Among ungulates, the perissodactyls-particularly equids - show the highest incidence of male infanticide (Pluháček and Bartoš 2005). The majority of reports have come from captivity, however, which has lead to suggestions that the behavior is an artifact of captivity or domestication (Table 1). Moreover, there is little unambiguous evidence from either the captive or few wild studies that infanticide shortens interbirth intervals in females, as predicted by the sexual selection hypothesis (e.g., Feh and Munkhtuya 2008). If there is an adaptive basis to the behavior, a variant of this hypothesis may be more relevant. This alternative hypothesis arose originally from an appreciation that the sexually selected mechanism is unlikely to operate in seasonal breeders, because infanticide cannot easily accelerate female return to fertilizable condition when mating is determined primarily by photoperiodicity or other cyclical cues. However, premature termination of lactation can potentially benefit males in seasonal breeders if it improves the female condition and thus her future reproductive success (Hrdy and Hausfater 1984; Hoogland 1985). Bartoš and Madlafousek's (1994) experimental study of red deer (Cervus elaphus) was the first to provide some empirical support for this hypothesis, which has been invoked for other mammals, including some primates, rodents, and equids (see Sexual selection II in Table 1). Another context in which sexually selected infanticide may operate among seasonal breeders is, of course, when interbirth intervals exceed $1 \mathrm{yr}$, as in langurs living at high elevations (Borries 1997). Under this scenario, infanticide can accelerate the return of females to fertilizable condition, and thereby enhance the reproductive success of a male (assuming he retains breeding status in the subsequent reproductive season).

Among the Sciuridae, male infanticide is known to occur in 11-14 species (Ebensperger and Blumstein 2007). In stark contrast to the mostly laboratory-based research on murids, almost all of the sciurid data are from the wild, particularly from studies of prairie dogs (Cynomys spp.), ground squirrels (Spermophilus spp.), and marmots (Marmota spp.). With few exceptions (e.g., nonseasonally breeding tree squirrels) (Solomon and Keane 2007), these naturalistic data are generally less consistent with the sexual selection hypothesis than with alternative explanations (e.g., nutritional exploitation) (see Table 1). Indeed, Hoogland (2007) has argued that his large data set on wild black-tailed prairie dogs (Cynomys ludovicianus) and Utah prairie dogs (C. parvidens) does not clearly support any of the existing hypotheses for male infanticide. Perhaps Blumstein's (2000, p. 195) appeal of more than a decade ago_- "we simply need better data”-remains the most compelling conclusion.

Another functional hypothesis for male infanticide has arisen from avian research. Sexually selected infanticide has been suggested for at least 13 species of birds (Veiga 2000). It has been reported in polygynous species (as expected theoretically), but notably also in socially monogamous breeders as well, where more often than advancing the female's next fecund period, infanticide functions as part of a takeover strategy for achieving breeding space and/or acquiring a mate in the first place. This role of infanticide has also been suggested for several species of mammals (see Table 1).

Perhaps no single species has yielded more proposed explanations for male infanticide than the chimpanzee (P. troglodytes) (Table 1$)$. Much about infanticide in this ape has long been puzzling (Arcadi and Wrangham 1999). This is particularly true of the violent attacks on the infants of neighboring groups, which have seemed to produce no obvious matingor resource-related benefits for the male perpetrators. Intriguing new data, however, suggest a "range expansion" function, whereby infanticide induces victimized mothers to abandon their home ranges to the killers, which in one Ugandan community facilitated a $22 \%$ increase in their territory size (Mitani et al. 2010).

Finally, two hypotheses explain infanticide as maladaptive behavior or accidental byproduct (Table 1 ). Inspired partly by laboratory demonstrations of infanticide arising from 
debilitating overcrowding (e.g., Myers and Poole 1961; Calhoun 1962), the social pathology hypothesis links the behavior in the wild to anthropogenic disturbance of either a direct (e.g., provisioning) or indirect (e.g., habitat degradation) nature. Although this explanation may apply to some individual cases (especially in captivity), it has largely failed as a general explanation, partly because the prediction that "the infanticidal individual is behaving in a manner that indicates malfunction" (Pierotti 1991, p. 1141) has not been consistently supported. Sterck (1998) argues that rather than produce infanticide by disrupting "normal" regulatory pathways of behavior, local human disturbance often alters rates of infanticide through its effects on important causal variables and conditions, such as the occurrence of male takeovers. Some anthropogenic intervention has also provided difficult-to-obtain "experimental" support of the sexual selection hypothesis (e.g., the selective removal of males through trophy hunting in fissiped carnivores) (e.g., Wielgus and Bunnell 2000; Loveridge et al. 2007; Wielgus et al. 2013; but see Miller et al. 2003).

The second nonadaptive hypothesis, the "generalized aggression" hypothesis, suggests that infanticide arises accidentally as a byproduct of the intra- or intersexual aggression surrounding male mating competition (Bartlett et al. 1993). Again, although some individual episodes are consistent with this model (Table 1 ), it has not proved an adequate general explanation of larger data sets, which typically establish the highly "directed" nature of infanticidal attacks and their predictable long-term patterning. One notable exception seems to be the wellstudied otariid seals, in which evidence suggests that infants (and juveniles) are trampled to death accidentally by huge males (although even in this case, adaptive hypotheses have been proffered but not tested) (see Table 1).

The Occurrence of Male Infanticide as a Potential Selective Agent for Female Counterstrategies

A defining feature of infanticide is its variability, expressed across taxa and over time. Rates of occurrence may vary significantly across populations of the same species. For example, in chacma baboons of southern Africa (Papio hamadryas ursinus), male infanticide accounts for an average of $38 \%$ of infant mortality, but among east African yellow (P. h. cynocephalus) and olive baboons ( $P$. $h$. anubis), it is not only much less demographically significant but less clearly a male reproductive strategy (Palombit 2003; for other examples, see also Butynski 1990; Arcadi and Wrangham 1999). Even in populations with relatively high rates of infanticide, it is not invariably expressed by all males experiencing the putative causal conditions. This has led some researchers to propose that infanticide is a facultative strategy (a behavioral polymorphism?) (e.g., McLean 1983; Palombit et al. 2000; Cords and Fuller 2010), as also suggested by theoretical models (e.g., Chapman and Hausfater 1979; Glass et al. 1985; Yamamura et al. 1990; Broom et al. 2004). Consequently, rates of occurrence in an "infanticidal" population may vary considerably over time. For example, although male infanticide accounted for an average of $38 \%$ of infant mortality in the previously mentioned chacma baboon population, this figure ranged from nearly $0 \%$ to as high as $75 \%$ in certain years (Cheney et al. 2004). The reasons for variation in infanticide are not well understood, but one relevant variable for interpopulation differences in primates as well as carnivores is the rate of breeding male turnover (Packer et al. 1988; Sterck 1998; Crockett and Janson 2000).

Long-term studies of populations in which male infanticide occurs have generally suggested it is a major-if not the major-source of infant mortality. Among Serengeti lions (P. leo), it accounts for $27 \%$ of cub mortality overall, but nearly $100 \%$ of the mortality of cubs under the age of 9 mo (Pusey and Packer 1994b). In a sample of 29 primate populations in which infanticide is known, 19 had relative rates $\geq 30 \%$ (Palombit 2012). In some of these taxa, male replacement produces a 3-, 11-, or 32-fold increase in infant mortality (Beehner and Bergman 2008; Fedigan et al. 2008; Pavé et al. 2012). In sciurid rodents, male (as well as female) infanticide is a major cause of infant and juvenile mortality (Ebensperger and Blumstein 2007). 
R.A. Palombit

In total, the empirical evidence for adaptive strategies of male infanticide provides a compelling rationale for evaluating its possible importance as a selective agent on the evolution of female biology.

\section{THE SEXUAL CONFLICT OF INFANTICIDE: FEMALE COUNTERSTRATEGIES}

Avery large number of possible female counterstrategies to male infanticide have been proposed and studied to varying degrees. These can be grouped into three broad categories addressing: (1) sexual behavior and reproduction; (2) individual prevention and deterrence; and (3) social counterstrategies. Space limitations preclude discussion of all of these phenomena, and so I focus on some of the major empirically supported patterns.

\section{Sexual and Reproductive Counterstrategies of Females}

Among the numerous potential counterstrategies related to sex and reproduction (Table 2), arguably the best known is "confusing paternity" through copulation with males (Hrdy 1979). Direct tests of this hypothesis are limited primarily to laboratory murids (see below), but field data have generally suggested that infanticide is perpetrated by males who have no sexual history with the victimized infants' mothers. In one of the few direct tests in primates, DNA paternity data showed that male attacks on infants were directed at eight times the rate toward unrelated individuals than toward offspring (Soltis et al. 2000).

A logical extension of this hypothesis is that females vulnerable to infanticide will pursue a strategy of "promiscuous" or "multimale" mating, which Hrdy (1979, 1981) invoked to explain the pronounced sexual assertiveness of haplorrhine primates. Broad comparative analyses provide indirect support for this hypothesis. For example, in eutherian mammals, multimale mating is more pronounced in species characterized by male infanticide; among primates alone, $62 \%$ of species with female susceptibility to infanticide show promiscuity, compared to $11 \%$ of nonvulnerable species (van Noordwijk and van Schaik 2000). Recent data have even suggested a heretofore unappreciated potential for this benefit to accrue to females living in unimale groups, through copulations with extragroup males (Palombit 2012). Similarly, Wolff and MacDonald (2004) argue on the basis of their correlative analysis that multimale mating in rodents is best understood as anti-infanticidal confusion of paternity, but it is important to remember that multimale mating has many other possible functions which are implicated in numerous species (e.g., Bryja et al. 2008; Lane et al. 2008). Notably, Hoogland (2007) rejects this hypothesis for Utah prairie dogs based on observations of males attacking some of the pups of females with whom they previously mated. However, students of species in which females produce multiply sired litters have speculated that males may be able to recognize kin phenotypically and then selectively target unrelated infants in a litter (e.g., Vestal 1991; Berdoy and Drickamer 2007). If true, this outcome would imply a possible male counterstrategy to counteract the female antiinfanticide counterstrategy of promiscuity (Table 2).

A large number of laboratory tests of this hypothesis in murid rodents suggest that copulation inhibits subsequent infanticidal behavior of males in at least seven species (reviewed in Ebensperger and Blumstein 2007). These results have not been replicated in several studies, however, which sometimes indicate the importance of not just copulation but a period of postcopulatory cohabitation in facilitating inhibition of infanticidal tendencies (e.g., Elwood and Kennedy 1994).

More intriguingly, a series of experiments on the house mouse suggest that this female counterstrategy of promiscuity may have itself selected for additional male counterstrategies. Copulation is known to inhibit infanticide in males (vom Saal and Howard 1982). That inhibition, however, does not commence until about $12 \mathrm{~d}$ after the sexual encounter, and it terminates spontaneously $60 \mathrm{~d}$ later, a schedule that corresponds roughly to the periods of gestation and lactation, respectively (vom Saal 
Table 2. Sexual and reproductive counterstrategies of females with selected example taxa

\begin{tabular}{|c|c|}
\hline $\begin{array}{l}\text { Proposed } \\
\text { counterstrategy }\end{array}$ & Theoretical rationale \\
\hline \multicolumn{2}{|c|}{ Strategies obscuring paternity among males } \\
\hline $\begin{array}{l}\text { Promiscuity/ } \\
\text { multimale mating }\end{array}$ & $\begin{array}{l}\text { Elevated sexual receptivity } \\
\text { and proceptivity and/or } \\
\text { polyestrous cycling } \\
\text { promotes insemination } \\
\text { by multiple males, } \\
\text { thereby confusing } \\
\text { paternity }\end{array}$ \\
\hline
\end{tabular}

Multiply sired litters

Extended estrus period

Concealed ovulation

Postconception sexual behavior

Situation-dependent sexual receptivity (“pseudoestrus”)
In polytocous breeders, females achieve fertilizations by multiple males in single litters

Lengthened periods of estrus or polyestrous cycling increase opportunities for copulation with multiple males

Paternity is obscured by absence of reliable signals of ovulation and/or by variability in the timing of ovulation

Anovulatory copulations (and when relevant, signaling of "ovulation") occur regularly in early gestation

Exposure to new (or extragroup) males facultatively causes (a) "deceptive" anovulatory sexual behavior in pregnant females; or (b) longer receptive periods among cycling females

Proposed example taxa

References

Birds (Tachycineta bicolor); murid rodents (Mus musculus); prairie dogs (Cynomys parvidens); bears (Ursus arctos); lions (Panthera leo); badgers (Meles meles); dolphins (Tursiops spp.); primates

Mice (M. musculus); voles (Myodes rufocanus); bears (U. arctos)

Dolphins (Tursiops); catarrhine primates with sexual swellings, langurs (S. entellus)

Hanuman langurs

(S. entellus); vervet monkeys (Chlorocebus pygerythrus); capuchin monkeys (Cebus capucinus)

Many catarrhine primates, some platyrrhine primates
Bertram 1975; Robertson 1990; Connor et al. 1996; 2000; Dahle and Swenson 2003;

Ebensperger and Blumstein 2007; Hoogland 2007; Dugdale et al. 2011; see references in Palombit 2012

Bellemain et al. 2006a; Ishibashi and Saitoh 2008; Thonhauser et al. 2013

Connor et al. 1996; van Schaik et al. 2000; Heistermann et al. 2001

Andelman 1987; Heistermann et al. 2001; Carnegie et al. 2006

See references in Palombit 2012

(a) Lemurs (Propithecus verreauxi); capuchin monkeys (Cebus apella); blue monkeys (Cercopithecus mitis); baboons (Papio hamadryas hamadryas); red colobus (Procolobus badius); (b) cercopithecine monkeys (C. mitis, Macaca fuscata) (a) Struhsaker and Leland 1985; Fairgrieve 1995; Brockman and Whitten 1996; Zinner and Deschner 2000; Pazol 2003; Ramírez-Llorens et al. 2008; (b) Cords 1984; Takahata et al. 1994; Pazol 2003

\section{Strategies focusing copulations and/or conceptions on particular male(s)}

Female mate choice targeting infanticidal male(s)
Females mate preferentially $\mathrm{M}$ with males most likely to commit infanticide because of factors such as dominance status or spatial proximity

\section{Murid rodents (Lemmus,} Microtus, Mus, Myodes); bears (U. arctos); capuchin monkeys (C. nigritus, C. olivaceous)
O’Brien 1991; Agrell et al. 1998; Bellemain et al. 2006b; Izar et al. 2009 
R.A. Palombit

Table 2. Continued

\begin{tabular}{|c|c|c|c|}
\hline $\begin{array}{l}\text { Proposed } \\
\text { counterstrategy }\end{array}$ & Theoretical rationale & Proposed example taxa & References \\
\hline $\begin{array}{l}\text { Female mate choice } \\
\text { targeting protector } \\
\text { male }(\mathrm{s})(\text { direct })\end{array}$ & $\begin{array}{l}\text { Females limit periovulatory } \\
\text { matings to a male likely } \\
\text { to be a future protector } \\
\text { against infanticide }\end{array}$ & $\begin{array}{l}\text { Hamadryas baboons } \\
\text { (P. h. hamadryas) }\end{array}$ & $\begin{array}{l}\text { Swedell and Saunders } \\
\quad 2006\end{array}$ \\
\hline $\begin{array}{l}\text { Female mate choice } \\
\text { targeting protector } \\
\text { male(s) (indirect) }\end{array}$ & $\begin{array}{l}\text { Females incite male mate } \\
\text { guarding by advertising } \\
\text { ovulation or copulations } \\
\text { (e.g., through sexual } \\
\text { swellings, vocalizations), } \\
\text { which reduces polyandry } \\
\text { at ovulation and thereby } \\
\text { concentrates paternity in } \\
\text { future, high-quality male } \\
\text { defender of infant }\end{array}$ & $\begin{array}{l}\text { Catarrhine primates living in } \\
\text { multimale societies }\end{array}$ & $\begin{array}{l}\text { See references in Palombit } \\
2012\end{array}$ \\
\hline \multicolumn{4}{|c|}{ Strategies manipulating reproduction } \\
\hline $\begin{array}{l}\text { Pregnancy block and } \\
\text { pregnancy } \\
\text { termination (Bruce } \\
\text { effect) }\end{array}$ & $\begin{array}{l}\text { Direct or indirect exposure } \\
\text { to a new replacement } \\
\text { male results in failure of } \\
\text { implantation or } \\
\text { absorption of fetus }\end{array}$ & $\begin{array}{l}\text { Equids (E. burchelli, } \\
\text { E. caballus); baboons } \\
\text { (P. h. hamadryas, } \\
\text { P. h. cynocephalus); langurs } \\
\text { (S. entellus); geladas } \\
\text { (Theropithecus gelada) }\end{array}$ & $\begin{array}{l}\text { Berger 1983; Pereira 1983; } \\
\text { Agoramoorthy et al. } \\
\text { 1988; Colmenares and } \\
\text { Gomendio 1988; } \\
\text { Pluháček and Bartoš } \\
\text { 2000; Bartoš et al. 2011; } \\
\text { Roberts et al. } 2012\end{array}$ \\
\hline Superfetation & $\begin{array}{l}\text { Conception occurs during } \\
\text { gestation accompanied } \\
\text { by fertilized eggs entering } \\
\text { embryonic diapause }\end{array}$ & $\begin{array}{l}\text { European badger (Meles } \\
\text { meles) }\end{array}$ & Yamaguchi et al. 2006 \\
\hline $\begin{array}{l}\text { Abandonment of } \\
\text { infant }\end{array}$ & $\begin{array}{l}\text { Mothers abandon a healthy } \\
\text { infant or an infant } \\
\text { injured in infanticidal } \\
\text { attack }\end{array}$ & $\begin{array}{l}\text { Colobine monkeys (Colobus } \\
\text { vellerosus, S. entellus) }\end{array}$ & $\begin{array}{l}\text { Hrdy 1977; Sicotte et al. } \\
\quad 2007\end{array}$ \\
\hline $\begin{array}{l}\text { Acceleration of } \\
\text { weaning }\end{array}$ & $\begin{array}{l}\text { Following male takeover, } \\
\text { mothers wean older } \\
\text { infants sooner than usual }\end{array}$ & $\begin{array}{l}\text { Vervet monkeys (Chlorocebus } \\
\text { pygerythrus); baboons } \\
\text { (P. h. hamadryas) }\end{array}$ & $\begin{array}{l}\text { Fairbanks and McGuire } \\
\text { 1987; Colmenares and } \\
\text { Gomendio } 1988\end{array}$ \\
\hline $\begin{array}{l}\text { Temporarily reduced } \\
\text { fecundity }\end{array}$ & $\begin{array}{l}\text { Following male takeover, } \\
\text { females temporarily } \\
\text { suspend ovulatory cycles } \\
\text { until new male(s) are } \\
\text { established and unlikely } \\
\text { to be replaced again }\end{array}$ & $\begin{array}{l}\text { Lions (Panther leo); leaf } \\
\text { monkeys (P. thomasi) }\end{array}$ & $\begin{array}{l}\text { Pusey and Packer 1994b; } \\
\text { Steenbeek 1999b }\end{array}$ \\
\hline Breeding synchrony & $\begin{array}{l}\text { Among group-living } \\
\text { females, greater ovulatory } \\
\text { synchronization prevents } \\
\text { single males from } \\
\text { monopolizing matings, } \\
\text { generating multimale } \\
\text { groups that are generally } \\
\text { less vulnerable to } \\
\text { takeover infanticide }\end{array}$ & $\begin{array}{l}\text { Lions (P. leo); lemurs } \\
\text { (Eulemur fulvus rufus); } \\
\text { baboons (Papio spp.); blue } \\
\text { monkeys (Cercopithecus } \\
\text { mitis) }\end{array}$ & $\begin{array}{l}\text { Bertram 1975; Cords } \\
\text { 1986; Altmann 1990; } \\
\text { Ostner and Kappeler } \\
2004\end{array}$ \\
\hline
\end{tabular}


1985; Perrigo et al. 1990, 1992). This timing suggests that the female (sexual) counterstrategy has, in turn, selected for counteradaptations in males that "fine-tune" the expression of infanticidal inhibition to periods when pups are most likely to be their genetic offspring, and that thereby avoid the "evolutionary mistake" of failing to attack unrelated pups. A further step in this coevolutionary scenario is suggested by the fact that aggressive mothers protecting their pups attack males who have copulated with them very recently (within the last $24 \mathrm{~h}$ ) with the same severity they direct toward males who have not copulated with them at all (Parmigiani et al. 1988b). Taken together, these patterns imply the spiraling, antagonistic dynamic characterizing sexual conflict.

Recognition of the potential importance of male protectors in deterring infanticide in some species (see below) has led to modification of this hypothesized counterstrategy of paternity confusion. Under these conditions, females may benefit most from pursuing a dual sexual strategy that concentrates paternity in the best available male defender and also dilutes (confuses) it in other males (e.g., Clarke et al. 2009). Cues of ovulation, such as the sexual swellings characterizing many species of Old World monkeys and apes, may provide a mechanism for achieving what seem at first glance to be incompatible reproductive goals. The "graded signal hypothesis" holds that: (1) the probability of ovulation is highest at the time of maximal tumescence, and thus sexual swellings can promote fertilization by high-quality (protector) males; but (2) the probability of ovulation at other times is inherently variable and nonzero, and, hence, paternity can be confused among other males (Nunn 1999). Hormonal data from langurs confirmed that the timing of ovulation was sufficiently variable that low-ranking males occasionally achieved fertilizations despite the dominant male's sexual monopolization of females during periods when ovulation was statistically more likely (Heistermann et al. 2001). Further support for this hypothesis is provided by observations that female primates of several species mate selectively at periovulatory periods (coinciding with increased probability of ovu- lation) and promiscuously at other times in their cycle (when ovulation is less likely to occur) (reviewed Palombit 2012). Moreover, in catarrhine primates exhibiting sexual swellings, the follicular phase of the menstrual cycleduring which follicles mature in the ovary and ending with ovulation-is significantly longer in species in which females are subject to higher risk of male infanticide (van Schaik et al. 2000). One interpretation of this pattern is that longer phases provide greater opportunities for matings to confuse paternity.

A recently suggested angle on this coevolutionary dialectic is that males may themselves exploit this female counterstrategy to protect their offspring. Evidence from chacma baboons suggests that alpha males may "cede" a proportion of mating opportunities to other males and thereby reduce the risk of infanticidal attack (Boyko and Marshall 2009; Henzi et al. 2010).

\section{Individual Counterstrategies of Females}

A number of possible deterrent counterstrategies are based on individual action (Table 3 ). Maternal (or postpartum) aggression, the "fierce and persistent" hostility of pregnant or lactating females to intruders is a conspicuous feature of rodent reproductive biology (Lonstein and Gammie 2002, p. 869) and is argued to underlie female territoriality in some species (Wolff and Peterson 1998; but see Ebensperger 1998a). Although maternal aggression is a heterogeneous phenomenon subserving multiple functions, a link to infanticide prevention is currently suggested in at least eight murid species and possibly several sciurid species (reviewed Ebensperger and Blumstein 2007; McGuire and Bemis 2007; Weber and Olsson 2008). Once again, numerous detailed data have emerged from laboratory investigations of murids. In species such as the house mouse, the aggressiveness of mothers is striking in light of the virtual absence of aggression when females are in other reproductive states (Heiming et al. 2013). Aggression is sensitive to the presence of pups (Elwood et al. 1990), increases with litter size (Maestripieri and Alleva 1990; see also 
R.A. Palombit

Table 3. Individual counterstrategies of females with selected example taxa

\begin{tabular}{|c|c|c|c|}
\hline $\begin{array}{l}\text { Proposed } \\
\text { counterstrategy }\end{array}$ & Theoretical rationale & Proposed example taxa & References \\
\hline $\begin{array}{l}\text { Maternal } \\
\text { aggression }\end{array}$ & $\begin{array}{l}\text { Females increase in } \\
\text { heterosexual } \\
\text { aggressiveness during } \\
\text { lactation and/or directly } \\
\text { defend infants from } \\
\text { infanticidal attacks by } \\
\text { males; females become } \\
\text { territorial during periods } \\
\text { of offspring rearing }\end{array}$ & $\begin{array}{l}\text { Birds (H. rustica, Tachycineta } \\
\text { bicolor); many murid } \\
\text { rodents, gerbils (Gerbilliscus } \\
\text { leucogaster); shrews (Sorex } \\
\text { araneus) }\end{array}$ & $\begin{array}{l}\text { Møller 1988; Robertson } \\
\text { 1990; Wolff and Peterson } \\
\text { 1998; Ebensperger and } \\
\text { Blumstein 2007; Lötter } \\
\text { and Pillay 2012; } \\
\text { Oleinchenko 2012 }\end{array}$ \\
\hline $\begin{array}{l}\text { Female } \\
\text { dominance }\end{array}$ & $\begin{array}{l}\text { Female maintains a } \\
\text { relationship of social } \\
\text { dominance over males } \\
\text { either during lactation or } \\
\text { more permanently }\end{array}$ & $\begin{array}{l}\text { Gerbils (M. unguiculatus); } \\
\text { ring-tailed lemurs (Lemur } \\
\text { catta) }\end{array}$ & $\begin{array}{l}\text { Pereira and Weiss 1991; } \\
\text { Elwood and Kennedy } \\
\text { 1994; Ichino } 2005\end{array}$ \\
\hline $\begin{array}{l}\text { Maternal } \\
\text { protectiveness }\end{array}$ & $\begin{array}{l}\text { Under conditions of } \\
\text { heightened infanticide } \\
\text { risk, mothers increase } \\
\text { visual monitoring of } \\
\text { potentially infanticidal } \\
\text { male and/or offspring, } \\
\text { and restrain and/or } \\
\text { maintain proximity to } \\
\text { infants more }\end{array}$ & $\begin{array}{l}\text { Horses (E. caballus); many } \\
\quad \text { primates }\end{array}$ & $\begin{array}{l}\text { Cameron et al. 2003, 2009; } \\
\text { see references in Palombit } \\
2012\end{array}$ \\
\hline $\begin{array}{l}\text { Chemical } \\
\text { suppression }\end{array}$ & $\begin{array}{l}\text { Pregnant females produce } \\
\text { pheromone that disrupts } \\
\text { neurochemical pathways } \\
\text { mediating infanticidal } \\
\text { behavior in males }\end{array}$ & Rats (R. norvegicus) & Mennella and Moltz 1988 \\
\hline $\begin{array}{l}\text { Sexual } \\
\text { segregation }\end{array}$ & $\begin{array}{l}\text { Lactating females (a) alter } \\
\text { individual ranging to } \\
\text { avoid areas with } \\
\text { potentially infanticidal } \\
\text { males; or (b) for } \\
\text { gregarious females, adjust } \\
\text { intragroup spatial } \\
\text { relations to decrease } \\
\text { proximity to infanticidal } \\
\text { males or reduce } \\
\text { participation in } \\
\text { intergroup encounters }\end{array}$ & $\begin{array}{l}\text { (a) Lions (Panthera pardus); } \\
\text { bears (U. arctos); spider } \\
\text { monkeys (Ateles spp.); } \\
\text { chimpanzees (P. troglodytes); } \\
\text { (b) baboons (P. h. ursinus); } \\
\text { capuchin monkeys } \\
\text { (C. capucinus) }\end{array}$ & $\begin{array}{l}\text { (a) Wrangham and Smuts } \\
\text { 1980; Packer and Pusey } \\
\text { 1983, 1994b; McComb } \\
\text { et al. 1993; Sakura 1994; } \\
\text { Matsumoto-Oda 1999; } \\
\text { Wielgus and Bunnell } \\
\text { 2000; Dahle and Swenson } \\
\text { 2003; Ben-David et al. } \\
\text { 2004; Aureli et al. 2008; } \\
\text { (b) Palombit et al. 2001; } \\
\text { Crofoot } 2007\end{array}$ \\
\hline
\end{tabular}

Koskela et al. 2000), and wanes as pups mature (Parmigiani et al. 1994). Moreover, in their defensive responses to the infanticidal threat posed by sexually naïve males, lactating females direct "severe" bites to vulnerable body parts (such as the head and ventrum) at 3-5 times the rate they do so in aggressive interactions with (less infanticidal) virgin females (Parmigiani et al. 1988a, 1990). Mothers can also differentiate among males on the basis of infanticidal potential and respond accordingly (Elwood et al. 1990). A possible indication of sexually antago- 
Infanticide as Sexual Conflict

nistic coevolution in this domain is that the magnitudes of male infanticidal behavior and maternal aggression are positively correlated with one another in genetic strains of mice (Parmigiani et al. 1999).

The actual effectiveness of maternal aggression in deterring male infanticide in rodents is debated, however. In the laboratory, male mice retaliate with extreme aggression, particularly against females with whom they have not mated (or have mated only recently), often overcoming maternal defense and successfully committing infanticide, leading Parmigiani et al. (1989) to conclude that maternal aggression may simply "delay," rather than prevent, infanticide (see also Ebensperger 1998b). Ebensperger and Blumstein (2007), however, suggest that under more naturalistic conditions, such a delay would probably often translate into maternal success. On the other hand, these researchers point out that ineffectiveness does seem to characterize maternal aggression in several species of squirrel, and they explicitly raise the possibility that this may reflect different outcomes or phases in sexually antagonistic coevolution.

Similarly, primate mothers mount concerted and protracted defense of their infants against infanticidal males, but once again evidence suggests that such efforts succeed in only a handful of species (Palombit 2012), some of which are characterized by the relatively rare social arrangement of stable female dominance over males (which also applies to some rodent examples, Elwood and Kennedy 1994). The reasons for this general ineffectiveness remain unclear, but they may partly reflect a greater reliance of female primates on socially based counterstrategies (see below).

A final individual counterstrategy has been suggested in several mammalian species characterized by solitariness or fission-fusion/dispersed gregariousness. In these species, lactating females may pursue a strategy of evasion based on sexual segregation (Table 2). There is evidence that even females in highly gregarious species may adopt this counterstrategy on a smaller spatial scale by adjusting behavior to decrease proximity to potentially infanticidal males residing in their groups (see Table 2).

\section{Social Counterstrategies of Females}

A large set of potential counterstrategies involve deterrence through cooperation with conspecifics. These can be grouped into two sets of strategies involving social interactions with other females and with males, respectively (Table 4).

Female gregariousness has traditionally been viewed as an adaptive solution to the problems of predation and feeding ecology (e.g., Alexander 1974; Wrangham 1980), and it is only recently that the selective role of infanticide risk has begun to be formally incorporated into these models (e.g., Sterck et al. 1997). There are several possible mechanisms through which group living potentially reduces infanticide risk: dilution effects (sensu Hamilton 1971), early detection through communal vigilance and alarm-based avoidance of infanticidal males; female-female coalitionary aggression to extragroup males to prevent takeover or to resident males to thwart attacks on infants. As with ecological models, related females may be more likely to join together in this manner (e.g., lions, see below), but aggregations of unrelated females to reduce infanticidal threat have also been suggested (e.g., Maestripieri and Rossi-Arnaud 1991; Cameron et al. 2009).

Although female gregariousness has been invoked as a counterstrategy for a number of species (Table 4), direct evidence for the predicted inhibitory effect on infanticide is still relatively rare. In a study of a seminatural population of house mice, Manning et al. (1995) reported that female communal nests experienced less than half the rate of infanticide (by both sexes) than did single-mother nests. A possible mechanism underlying this outcome is suggested by laboratory experiments demonstrating that paired females effectively repel male (and female) intruders (Parmigiani 1986; Maestripieri and Rossi-Arnaud 1991). Similarly, when food was experimentally manipulated to promote increased aggregation of female bank voles (Myodes glareolus), pup survival increased, which Rémy et al. (2013) attributed to improved anti-infanticide protection.

There are several lines of evidence that group living among lionesses (Panthera leo) is 
R.A. Palombit

Table 4. Social counterstrategies of females with selected example taxa

\begin{tabular}{|c|c|c|c|}
\hline $\begin{array}{l}\text { Proposed } \\
\text { counterstrategy }\end{array}$ & Theoretical rationale & Proposed example taxa & References \\
\hline \multicolumn{4}{|c|}{ Social strategies involving other females } \\
\hline $\begin{array}{l}\text { Female-female } \\
\text { association }\end{array}$ & $\begin{array}{l}\text { (a) Females living in } \\
\text { permanent groups with } \\
\text { other females reduce } \\
\text { infanticide risk through } \\
\text { derive dilution, vigilance, } \\
\text { and/or defensive } \\
\text { benefits; (b) lactating } \\
\text { members of aggregate } \\
\text { temporarily with other } \\
\text { females }\end{array}$ & $\begin{array}{l}\text { (a) Voles (Microtus oeconomus, } \\
\text { Myodes glareolus); house } \\
\text { mice (M. musculus); Arctic } \\
\text { ground squirrels } \\
\text { (S. parryii); horses } \\
\text { (E. caballus); lions (P. leo); } \\
\text { dolphins (Tursiops spp.); } \\
\text { langurs (S. entellus); } \\
\text { primates generally; (b) } \\
\text { baboons (P. hamadryas } \\
\text { ursinus) }\end{array}$ & $\begin{array}{l}\text { (a) McLean 1982; Pusey } \\
\text { and Packer 1994a,b; } \\
\text { Brereton 1995; Manning } \\
\text { et al. 1995; Treves and } \\
\text { Chapman 1996; Connor } \\
\text { 2000; Le Galliard et al. } \\
\text { 2006; Cameron et al. } \\
\text { 2009; Rémy et al. 2013; } \\
\text { (b) Cowlishaw 1999; } \\
\text { Palombit et al. 2001 }\end{array}$ \\
\hline $\begin{array}{l}\text { Female coalitionary } \\
\text { defense }\end{array}$ & $\begin{array}{l}\text { Females collectively attack } \\
\text { infanticidal males and/or } \\
\text { deter male immigration } \\
\text { with relative success }\end{array}$ & $\begin{array}{l}\text { Lions (Panthera leo); sifakas } \\
\text { (Propithecus edwardsi, } \\
\text { P. verreauxi); chimpanzees } \\
\text { (P. troglodytes); bonobo } \\
\text { (Pan paniscus); blue } \\
\text { monkeys (Cercopithecus } \\
\text { mitis); red colobus } \\
\text { (Procolobus badius); } \\
\text { bonobos (P. paniscus) }\end{array}$ & $\begin{array}{l}\text { Butynski 1982; Packer et al. } \\
\text { 1990; Richard et al. } \\
\text { 1993; Starin 1994; } \\
\text { Grinnell and McComb } \\
\text { 1996; de Waal 1997; } \\
\text { Morelli et al. 2009; } \\
\text { Cords and Fuller 2010 }\end{array}$ \\
\hline $\begin{array}{l}\text { Residency in small } \\
\text { (female) groups }\end{array}$ & $\begin{array}{l}\text { If risk of male takeover } \\
\text { increases with female } \\
\text { group size, females }\end{array}$ & $\begin{array}{l}\text { Lions }(P . \text { leo); many species of } \\
\text { colobine monkeys, howler } \\
\text { monkeys, gorillas }\end{array}$ & $\begin{array}{l}\text { Pusey and Packer 1987; see } \\
\text { references in Palombit } \\
2012\end{array}$ \\
\hline
\end{tabular}

maintain small groups via

secondary transfer, group

fission, and/or

aggression to female

immigrants

\section{Social strategies involving males} Transfer with
evicted male

Male-female association
In species in which infanticide is preceded by male takeover, lactating females temporarily accompany ousted male until infant is weaned

Females associate with individual male defender(s) as: (a) relatively loose association in dispersed societies; (b) temporary relationship with particular males in multimale groups during lactation; or (c) permanent male-female pairs or unimale groups
Capuchin monkeys (Cebus capucinus); colobine monkeys (Semnopithecus vetulus, S. entellus, Presbytis rubicunda)

Burying beetles (Nicrophorus spp.); birds (Troglodytes aedon); Arctic ground squirrels (S. parryii); muroid rodents; bears (U. arctos); lions (P. leo); dolphins (Tursiops spp.); many primates including mouse lemurs (Cheirogaleus major); howler monkeys (Alouatta spp.); mangabeys
Rudran 1973a; Hrdy 1977; Davies 1987; Jack and Fedigan 2009

McLean 1983; Freed 1986; Watts 1989; Trumbo 1990b, 2007; Gust 1994; Pusey and Packer 1994b; Kappeler 1997; Sommer 1997; Agrell et al. 1998; Borries et al. 1999b, 2011; Steenbeek 1999a; Connor et al. 2000; Crockett and Janson 2000; Delgado and van Schaik 2000; Weingrill 
Table 4. Continued

\begin{tabular}{|c|c|c|c|}
\hline $\begin{array}{l}\text { Proposed } \\
\text { counterstrategy }\end{array}$ & Theoretical rationale & Proposed example taxa & References \\
\hline & & $\begin{array}{l}\text { (Cercocebus atys, } \\
\text { C. galeritus); baboons } \\
\text { (P. hamadryas hamadryas, } \\
\text { P. h. ursinus); colobine } \\
\text { monkeys (Colobus } \\
\text { vellerosus, Procolobus } \\
\text { badius, P. thomasi, } \\
\text { S. entellus); gibbons } \\
\text { (Hylobates spp.); great apes } \\
\text { (Gorilla gorilla subspp., } \\
\text { Pongo pygmaeus) }\end{array}$ & $\begin{array}{l}\text { 2000; Stokes 2004; } \\
\text { Bellemain et al. 2006b; } \\
\text { Swedell and Saunders } \\
\text { 2006; Teichroeb and } \\
\text { Sicotte 2008; Palombit } \\
\text { 2009; Yamagiwa et al. } \\
\text { 2009; Fruteau et al. 2010; } \\
\text { Opie et al. } 2013\end{array}$ \\
\hline $\begin{array}{l}\text { Residency in } \\
\text { multimale } \\
\text { groups }\end{array}$ & $\begin{array}{l}\text { In female-dispersal systems, } \\
\text { females immigrate to } \\
\text { groups with more males; } \\
\text { in female-philopatric } \\
\text { systems, females promote } \\
\text { multimale group } \\
\text { structure }\end{array}$ & $\begin{array}{l}\text { Lemurs (Eulemur fulvus, } \\
\text { P. verreauxi); howler } \\
\text { monkeys (Alouatta } \\
\text { arctoidea, A. caraya, } \\
\text { A. palliata); cercopithecine } \\
\text { monkeys (Chlorocebus } \\
\text { pygerythrus, Macaca } \\
\text { fuscata); gorillas (Gorilla } \\
\text { gorilla beringei) }\end{array}$ & $\begin{array}{l}\text { Crockett and Janson 2000; } \\
\text { Treves 2001; Isbell et al. } \\
\text { 2002; Ostner and } \\
\text { Kappeler 2004; Yamada } \\
\text { and Nakamichi 2006; } \\
\text { Lewis 2008; Robbins } \\
\text { et al. 2009a; Pavé et al. } \\
2012\end{array}$ \\
\hline $\begin{array}{l}\text { Residency in } \\
\text { groups with } \\
\text { better male } \\
\text { defender }\end{array}$ & $\begin{array}{l}\text { Primarily among females } \\
\text { living in unimale } \\
\text { societies, cycling females } \\
\text { immigrate to a new group } \\
\text { with a better protector } \\
\text { male }\end{array}$ & $\begin{array}{l}\text { Colobine monkeys (Colobus } \\
\text { vellerosus, Procolobus } \\
\text { badius, } \text { P. rufomitratus, } \\
\text { P. thomasi); gorillas (Gorilla } \\
\text { gorilla subspp.) }\end{array}$ & $\begin{array}{l}\text { Marsh 1979; Starin 1994; } \\
\text { Sterck 1997; Stokes et al. } \\
\text { 2003; Robbins et al. } \\
\text { 2009b; Teichroeb et al. } \\
\text { 2009; Yamagiwa et al. } \\
\text { 2009 }\end{array}$ \\
\hline
\end{tabular}

an effective deterrent to infanticide (Packer and Pusey 1983). Cub mortality is much lower for females living in groups of two or more than for solitary mothers (Pusey and Packer 1994b). This is partly achieved through coalitionary attack on alien males, which successfully protects cubs from attack by single individuals or small groups of males, who "may have to fight for their lives" against lionesses capable of inflicting fatal injuries (Pusey and Packer 1994b, p. 297). The counterstrategic response of males is to use vocal cues to avoid groups of females (Grinnell and McComb 1996) or to travel in large male cohorts, against which female defense is less effective. Like house mouse dams, however, lionesses appear capable of discriminating among males on the basis of infanticide threat and may use evasion to reduce such interactions (McComb et al. 1993). Finally, socioecological data suggest that pride size does not maximize individual food intake through communal hunting, but rather infanticidal protection (Packer et al. 1990).

Somewhat surprisingly, female coalitionary defense against infanticidal males in most primates appears as generally unsuccessful as individual maternal defense (Palombit 2012). It is possible that the anti-infanticide advantage conferred by gregariousness involves the harder-to-test mechanism of improved vigilance and nonaggressive intervention (e.g., retrieving infants from dangerous situations before attacks can be launched, as has been noted in a number of field studies). In some primate species, however, an alternative version of this female-female counterstrategy may operate.

This alternative version is based on the idea that larger groups of females are predicted to be 
R.A. Palombit

more attractive as takeover targets to potentially infanticidal males. Thus, females may theoretically garner increased protection for their infants by breeding in relatively small groups (Janson and Goldsmith 1995; Treves and Chapman 1996). This goal can be achieved via several possible mechanisms, such as the fissioning of large groups, individual female transfer to smaller groups, or the aggressive deterrence of alien female immigration by resident females. Supportive evidence for this counterstrategy has been found in a number of primate species in which: (1) the predicted negative correlation between infant mortality or infanticide rates and female group size has been documented; and (2) one or more of the above three mechanisms has been identified (reviewed Palombit 2012; see also Pusey and Packer 1987 for lions). This counterstrategy carries a potentially important implication that may help to explain the surprising ineffectiveness of female coalitionary aggression against infanticide in many primates. The individual female transfer that underlies this counterstrategy in primates tends to produce small groups of females who share relatively low genetic relatedness with one another (cf. lions). Such conditions may impede the formation of the kinds of female-female coalitions that are effective deterrents to infanticidal males (Palombit 2012). This hypothesis has not been tested directly, but it underscores the possibility that various female counterstrategies may be incompatible with one another, such that adoption of one may preclude another.

A final set of counterstrategies has been inspired by a growing body of data demonstrating the important role males may play in preventing infanticide. The majority of relevant data on these counterstrategies has come from studies of nonhuman primates, possibly because other animals, such as rodents, are less likely to rely on socially based counterstrategies to infanticide (Blumstein 2000). There are several variants on this strategic theme, which can be distinguished by general features of social system, such as the feasibility of transfer as a strategic option for females at risk of infanticide (reviewed in Palombit 2012).
The ecological and social costs of intergroup transfer vary considerably for females, but they are generally expected to be higher for frugivorous species than for folivores. This is because the greater rarity of fruits (relative to leaves) in most environments engenders elevated feeding competition and greater difficulties in finding food in the unfamiliar habitats that a transferring female would necessarily encounter. Moreover, the social costs of female transfer are potentially higher for frugivores because the "female-bonded" social organization of many fruit-eating primates (particularly Old World monkeys) is centered on networks of social relationships among related females. Thus, female transfer may necessarily require cessation of cooperative interactions with female kin, which can impose costs on both individual and inclusive fitness. It is for these reasons that transfer is less of an option for females in the female-philopatric, multimale societies. In this case, an antiinfanticide counterstrategy based on cooperation with resident males would be more likely. One such possible counterstrategy is to maintain a temporary relationship with a male protector (or a small number of adult males) during the period of infant vulnerability (Table 4), as exemplified by the chacma baboon of southern Africa. When a female gives birth, she establishes such a relationship, or "friendship," with a particular male, which lasts as long as she has her nursing infant; if the infant weans or dies, the relationship ends. Observational and experimental playback data suggest that male friends are significantly more predisposed than other males to come to the aid of females under attack by the potentially infanticidal alpha male (Palombit et al. 1997), possibly because of paternity of the infants involved (Moscovice et al. 2010). Immigration of a new male who attains alpha status results in elevated cortisol among the group's mothers (but not among cycling females); cortisol levels climb even higher if an infanticide is successfully perpetrated or, notably, among the (very few) mothers who lack a male friend (Beehner et al. 2005; Engh et al. 2006). Lactating females compete for male friends, such that a mother's rank is positively correlated with the rank of her male friend (Palombit et al. 2001). 
It is partly because the vast majority of mothers have male friends that it is difficult to assess directly the fitness benefits of friendship for females, and data are still too few to evaluate how variation in the characteristics of friendships or male friends affect infant survival. Nevertheless, the evidence is suggestive that this system reflects an anti-infanticidal counterstrategy.

For folivorous primates, the costs of female transfer are predicted to be lower, opening the way for dispersal-based counterstrategies, such as the previously described transfer to smaller female groups. Many of these species are characterized by unimale breeding units, which are particularly prone to takeover infanticide. Females in these societies may reduce the risk of infanticide by choosing a group with a highquality male protector. This hypothesis has not been subject to rigorous testing, partly because of the difficulties in measuring variation in male quality as protector. There are suggestive supportive data for a few species, however, notably Thomas's leaf monkeys ( $P$. thomasi), in which infanticide is not perpetrated as part of a male "takeover" by a new immigrant, but rather by extragroup males. Victimized females respond to infanticide by abandoning their group and joining the killer. And, as predicted, cycling females who transfer from older males to "prime" (younger) males subsequently experience fewer infanticidal attacks.

For relatively folivorous primates in which female transfer remains an ecologically viable option, but in which the number of males in groups varies, an alternative counterstrategy is to preferentially target groups with more males. This hypothesis is supported in several species, such as howler monkeys (Alouatta spp.) and mountain gorillas ( $G$. gorilla beringei) in which there is empirical evidence that infanticide occurs at predictably lower rates in groups with more males (independently of female group size). Even so, puzzles remain, such as the apparent lack of preference among female gorillas for multimale groups as destinations for transfer (Robbins et al. 2009a).

The above examples have focused on gregarious animals, but even in dispersed societies in which the sexes are relatively solitary and inter- act sporadically, female association with a male may nevertheless afford some protection against infanticide (Table 4). For example, ousted male lions will re-establish or maintain residency near a pride that offers few mating opportunities if it contains vulnerable cubs they likely sired (Pusey and Packer 1994b). Male-female pairs of house mice repulse infanticidal intruders (Palanza et al. 1996) so successfully that Parmigiani et al. (1994) suggest that the apparent failure of maternal aggression to thwart infanticide in previous laboratory experiments may derive from the artificial absence of the stud male.

Finally, infanticide has been suggested to be the primary selective force behind the evolution of social monogamy (Table 4) (reviewed in Palombit 2000). Perhaps the most compelling evidence for this hypothesis comes from research on burying beetles (Nicrophorus spp.). In a manner reminiscent of avian monogamy, a male-female pair of beetles maintains a long period of postcopulatory association with one another on a vertebrate carcass that provides nourishment for developing larvae (Eggert and Müller 1997). Both parents provision the larvae by regurgitating predigested carrion obtained from this carcass, although the paternal contribution is not crucial for offspring success (Trumbo 1991; Müller et al. 1998). On the other hand, male presence significantly reduces the risk of takeover infanticide by another male, suggesting an anti-infanticide benefit of social monogamy in some populations (Trumbo 1990a,b, 1991; Robertson 1993; Trumbo and Valletta 2007). Similarly, in some birds such as tropical house wrens (Troglodytes aedon), protection against infanticide appears to be a more important advantage of social monogamy than biparental provisioning of offspring (Freed 1986; see also Veiga 2000). This hypothesis as it applies to primates, notably the monogamous gibbons (Hylobates spp.) (van Schaik and Dunbar 1990), has been questioned on the basis of comparative data (Palombit 1999; Fuentes 2000; Brockelman 2009), but recent indirect evidence of infanticide in one population of white-handed gibbons suggests an intriguing possibility (Borries et al. 2011). Contradictory conclusions about the 
R.A. Palombit

selective role of infanticide in the evolution of mammalian social monogamy have emerged from recent phylogenetic and life history analyses (Lukas and Clutton-Brock 2013; Opie et al. 2013).

\section{CONCLUSIONS}

Male infanticide appears to be an arresting example of interlocus conflict (sensu Arnqvist and Rowe 2005). There is still a great deal we do not understand about the array of behaviors constituting this system. The adaptive significance, occurrence, and variability of male infanticide remains unclear in many species, and we still lack enough data to compare directly the lifetime reproductive success of the "infanticidal" versus alternative "noninfanticidal" strategies. Nevertheless, evidence accumulated over the last several decades yields several general conclusions. First, in the well-studied populations, it seems clear that infanticide is not simply an aberration or byproduct of other biological characters or conditions, but represents an adaptive strategy for males in some circumstances. Second, the adaptive significance of the strategy is multifarious; male infanticide is not unitary. The sexual selection hypothesis may be the best known explanation, but there is sufficient evidence to consider a multiplicity of other functions (Table 1). Third, whatever the benefit of infanticide to males, there is little doubt that it usually imposes a substantive fitness cost on females (as well as infants, of course), particularly in the slowly reproducing species in which one form of infanticide-sexually selected-is expected to operate. This provides a strong rationale for expecting that male infanticide has acted as a selective agent in the evolution of female biology in these species, perhaps operating as strongly as the conventionally recognized contingencies related to predation and feeding ecology.

Female counterstrategies to infanticide have been the subject of rigorous study for a relatively short time, however. What is perhaps most striking about current data is the great variety of possibilities that have been proposed (Tables $2-4)$. These mechanisms range from counterstrategies that increase the potential costs of infanticide to would-be perpetrators (e.g., promiscuity, maternal aggression, coalitionary defense with other females or males), to those that decrease its benefits (promoting small female group sizes or multimale social structure), to some that simply "cut the losses" of infanticide (e.g., pregnancy termination). It is also striking that females in the well-studied populations appear multiple times throughout Tables 2-4, suggesting that females at risk of infanticide rely not on one counterstrategy but on an array of counterstrategies. Lions provide an excellent example of this principle. When cycling, lionesses mate promiscuously to confuse paternity (Table 2). During lactation, females with older cubs ( $\geq 10 \mathrm{mo}$ ) capable of independent locomotion opt for a strategy of evasion, living largely solitarily on the periphery of their home ranges (sexual segregation) (Table 3). Should alien males be encountered visually or aurally, females attempt to escape or resort to individual maternal aggression (Table 3) (although the latter counterstrategy carries potentially high costs). For females with younger, less mobile cubs, however, sexual segregation is less feasible, and they rely on membership in a pride of female relatives (especially if it is a larger pride) (Table 4). They thereby benefit from the coalitionary defense that is "always able to overcome or drive off one or a few males" (Pusey and Packer 1994b, p. 297). But if prides become too large and thus more attractive for male takeover, then females may disperse (Table 4). The more general conclusion suggested here is that sexually antagonistic coevolution may be a mechanism accounting for much of the great diversity of animal behavior.

There is an unquestionable need for further research on possible female counterstrategies. There are alternative explanations for most of the behaviors listed in Tables 2-4, which must be carefully tested (and rejected) to substantiate the anti-infanticide hypothesis. Analyses are additionally complicated by the fact that predictions of the anti-infanticide hypotheses are often similar to those of alternatives based on ecology. Finally, although it seems likely that female counterstrategies will help to explain variation in the occurrence of male infanticide, 
data from the wild are insufficient to address this issue quantitatively.

It should also be noted that the implications for sexually antagonistic coevolution may extend well beyond infanticide and its immediate counterstrategies. A case in point concerns the suite of behaviors collectively known as male "sexual coercion" of females. Those aspects of sexual coercion that involve restricting multimale mating by females may be best understood as the male evolutionary response to promiscuity as a female counterstrategy to the male strategy of infanticide (Wolff and MacDonald 2004; Palombit 2014). Similarly, female promiscuity may have exerted selection on systems of sperm competition among males in some taxa, which in turn may have then "counter selected" for mechanisms of cryptic female choice (Kappeler 2012). Thus, the potential cascading effects of the sexual conflict originating with infanticide may be extensive, broad, and diverse.

In many ways, the study of male infanticide and female counterstrategies does not lend itself well to the kinds of methodologies and reproductive profiles that allow direct assessment of sexually antagonistic coevolution (Palombit 2010). The relevant organisms often reproduce slowly, are not easily amenable to experimental manipulation, and are difficult to study in the wild. Despite these difficulties, however, these systems offer opportunities to study the action of sexual conflict in the context of highly gregarious life styles and, more generally, to broaden our appreciation of the diversity of pathways over which sexually antagonistic coevolution has operated.

\section{ACKNOWLEDGMENTS}

I thank William Rice and Sergey Gavrilets for inviting me to contribute to this volume. I am also grateful to S. Alavi, M. Janiak, S. Kivai, A. Moldawer, D. Prasetyo, and E. Vogel for discussion of the material for this manuscript.

\section{REFERENCES}

Agoramoorthy G, Mohnot SM. 1988. Infanticide and juvenilicide in hanuman langurs (Presbytis entellus) around Jodhpur, India. Hum Evol 3: 279-296.
Agoramoorthy G, Mohnot SM, Sommer V, Srivastava A. 1988. Abortions in free-ranging Hanuman langurs (Presbytis entellus) -A male induced strategy? Hum Evol 3: 297-308.

Agoramoorthy G, Rudran R. 1995. Infanticide by adult and subadult males in free-ranging red howler monkeys, Alouatta seniculus, in Venezuela. Ethology 99: 75-88.

Agrell J, Wolff JO, Ylönen H. 1998. Counter-strategies to infanticide in mammals: Costs and consequences. Oikos 83: 507-517.

Alexander RD. 1974. The evolution of social behavior. Annu Rev Ecol Syst 5: 325-383.

Altmann J. 1990. Primate males go where the females are. Anim Behav 39: 192-195.

Altmann J, Altmann SA, Hausfater G. 1978. Primate infant's effects on mother's future reproduction. Science 201: $1028-1029$.

Altmann J, Sayialel S, Bayes M, Bruford MW, Alberts SC. 2006. Cannibalism in baboons: Sexual selection versus hungry hunters. Int J Primatol 27 (Suppl 1): 315.

Andelman SJ. 1987. Evolution of concealed ovulation in vervet monkeys (Cercopithecus aethiops). Am Nat 129: 785-799.

Angst W, Thommen D. 1977. New data and discussion of infant killing in Old World monkeys and apes. Folia Primatol 27: 198-229.

Arcadi CA, Wrangham RW. 1999. Infanticide in chimpanzees: Review of cases and a new within-group observation from Kanyawara study group in Kibale National Park. Primates 40: 337-351.

Arnqvist G, Rowe L. 2005. Sexual conflict. Princeton University Press, Princeton, NJ.

Aureli F, Schaffner CM, Boesch C, Bearder SK, Call J, Chapman CA, Connor RC, di Fiore A, Dunbar RIM, Henzi SP, et al. 2008. Fission-fusion dynamics. Curr Anthropol 49: 627-654.

Bartlett TQ, Sussman RW, Cheverud JM. 1993. Infant killing in primates: A review of observed cases with specific reference to the sexual selection hypothesis. Am Anthropol 95: 958-990.

Bartoš L, Madlafousek J. 1994. Infanticide in a seasonal breeder: The case of the red deer. Anim Behav 47: $217-$ 219.

Bartoš L, Bartošová J, Pluháček J, Šindelářová J. 2011. Promiscuous behaviour disrupts pregnancy block in domestic horse mares. Behav Ecol Sociobiol 65: 1567-1572.

Beehner JC, Bergman TJ. 2008. Infant mortality following male takeovers in wild geladas. Am J Primatol 70: 11521159.

Beehner JS, Bergman J, Cheney DL, Seyfarth RM, Whitten PL. 2005. The effect of new alpha males on female stress in free-ranging baboons. Anim Behav 69: 111-1221.

Bellemain E, Swenson JE, Taberlet P. 2006a. Mating strategies in relation to sexually selected infanticide in a nonsocial carnivore: The brown bear. Ethology 112: 238-246.

Bellemain E, Zedrosser A, Manel S, Waits LP, Taberlet P, Swenson JE. 2006b. The dilemma of female mate selection in the brown bear, a species with sexually selected infanticide. Proc Roy Soc Lond B 273: 283-291. 
R.A. Palombit

Ben-David M, Titus K, Beier L. 2004. Consumption of salmon by Alaskan brown bears: A trade-off between nutritional requirements and the risk of infanticide? Oecologia 138: $465-474$

Berdoy M, Drickamer LC. 2007. Comparative social organization and life history of Rattus and Mus. In Rodent societies: An ecological and evolutionary perspective (ed. Wolff JO, Sherman PA), pp. 380-392. University of Chicago Press, Chicago.

Berger J. 1983. Induced abortion and social factors in wild horses. Nature 303: 59-61.

Berman C, Li J, Ogawa H, Ionica C, Yin H. 2007. Primate tourism, range restriction, and infant risk among Macaca thibetana at Mt. Huangshan, China. Int J Primatol 28: 1123-1141.

Bertram BC. 1975. Social factors influencing reproduction in wild lions. J Zool 177: 463-482.

Blumstein DT. 2000. The evolution of infanticide in rodents: A comparative analysis. In Infanticide by males and its implications (ed. van Schaik CP, Janson CH), pp. 178197. Cambridge University Press, Cambridge.

Boggess JE. 1984. Infant killing and male reproductive strategies in langurs (Presbytis entellus). In Infanticide: Comparative and evolutionary perspectives (ed. Hausfater G, Hrdy SB), pp. 283-310. Aldine, New York.

Borries C. 1997. Infanticide in seasonally breeding multimale groups of Hanuman langurs (Presbytis entellus) in Ramnagar (South Nepal). Behav Ecol Sociobiol 41: 139_ 150.

Borries C, Laundhard K, Epplen C, Epplen JT, Winkler P. 1999a. DNA analyses support the hypothesis that infanticide is adaptive in langur monkeys. Proc Roy Soc Lond B 266: 901-904.

Borries C, Launhardt K, Epplen C, Epplen JT, Winkler P. 1999b. Males as infant protectors in Hanuman langurs (Presbytis entellus) living in mulitmale groups: Defense pattern, paternity, and sexual behavior. Behav Ecol Sociobiol 46: 350-356.

Borries C, Savini T, Koenig A. 2011. Social monogamy and the threat of infanticide in larger mammals. Behav Ecol Sociobiol 65: 685-693.

Boyko RH, Marshall AJ. 2009. The willing cuckold: Optimal paternity allocation, infanticide and male reproductive strategies in mammals. Anim Behav 77: 1397.

Brereton AR. 1995. Coercion-defense hypothesis: The evolution of primate sociality. Folia Primatol 64: 207-214.

Brockelman WY. 2009. Ecology and the social system of gibbons. In The gibbons (ed. Lappan S, Whittaker D), pp. 211-239. Springer, New York.

Brockman DK, Whitten PL. 1996. Reproduction in freeranging Propithecus verreauxi: Estrus and the relationship between multiple partner matings and fertilization. $\mathrm{Am} \mathrm{J}$ Phys Anthropol 100: 57-69.

Brockman DK, Cobden AK, Whitten PL. 2009. Birth season glucocorticoids are related to the presence of infants in sifaka (Propithecus verreauxi). Proc Roy Soc Lond B 276: 1855-1863.

Broom M, Borries C, Koenig A. 2004. Infanticide and infant defence by males-Modelling the conditions in primate multi-male groups. J Theor Biol 231: 261-270.
Bryja J, Patzenhauerová H, Albrecht T, Mošanský L, Stanko M, Stopka P. 2008. Varying levels of female promiscuity in four Apodemus mice species. Behav Ecol Sociobiol 63: 251-260.

Butynski TM. 1982. Harem-male replacement and infanticide in the blue monkey (Cercopithecus mitis stuhlmanni) in the Kibale Forest, Uganda. Am J Primatol 3: 1-22.

Butynski TM. 1990. Comparative ecology of blue monkeys (Cercopithecus mitis) in high and low density subpopulations. Ecol Monogr 60: 1-26.

Caley J, Boutin S. 1985. Infanticide in wild populations of Ondatra zibethicus and Microtus pennsylvanicus. Anim Behav 33: 1036-1037.

Calhoun JB. 1962. Population density and social pathology. Sci Am 206: 139-148.

Cameron EZ, Linklater WL, Stafford KJ, Minot EO. 2003. Social grouping and maternal behaviour in feral horses (Equus caballus): The influence of males on maternal protectiveness. Behav Ecol Sociobiol 53: 92-101.

Cameron EZ, Setsaas TH, Linklater WL. 2009. Social bonds between unrelated females increase reproductive success in feral horses. Proc Natl Acad Sci 106: 13850-13853.

Carnegie SD, Fedigan LM, Ziegler TE. 2006. Post-conceptive mating in white-faced capuchins, Cebus capucinus: Hormonal and sociosexual patterns of cycling, noncycling, and pregnant females. In New perspectives in the study of Mesoamerican primates (ed. Estrada A, et al.), pp. 387409. Springer, New York.

Chapman M, Hausfater G. 1979. The reproductive consequences of infanticide in langurs: A mathematical model. Behav Ecol Sociobiol 5: 227-240.

Cheney DL, Seyfarth RM, Fischer J, Beehner J, Bergman T, Johnson SE, Kitchen DM, Palombit RA, Rendall D, Silk JB. 2004. Factors affecting reproduction and mortality among baboons in the Okavango Delta, Botswana. Int J Primatol 25: 401-428.

Clarke MR. 1983. Infant-killing and infant disappearance following male takeovers in a group of free-ranging howling monkeys (Alouatta palliata) in Costa Rica. Am J Primatol 5: 241-247.

Clarke PMR, Pradhan GR, van Schaik CP. 2009. Intersexual conflict in primates: Infanticide, paternity allocation, and the role of coercion. In Sexual coercion in primates and humans (ed. Muller MN, Wrangham RW), pp. 42-77. Harvard University Press, Cambridge, MA.

Colmenares F, Gomendio M. 1988. Changes in female reproductive condition following male take-overs in a colony of hamadryas and hybrid baboons. Folia Primatol 50: $157-174$.

Connor RC. 2000. Group living in whales and dolphins. In Cetacean societies: Field studies of dolphins and whales (ed. Mann J, et al.), pp. 199-218. University of Chicago Press, Chicago.

Connor RC, Richard AF, Smolker RA, Mann J. 1996. Patterns of female attractiveness in Indian Ocean bottlenosed dolphins. Behaviour 133: 37-69.

Connor RC, Read AJ, Wrangham RW. 2000. Male reproductive strategies and social bonds. In Cetacean societies: Field studies of dolphins and whales (ed. Mann J, et al.), pp. 247-269. University of Chicago Press, Chicago. 
Cords M. 1984. Mating patterns and social structure in redtail monkeys (Cercopithecus ascanius). Z Tierpsychol 64: 313-329.

Cords M. 1986. Promiscuous mating among blue monkeys in the Kakamega Forest, Kenya. Ethology 72: 214-226.

Cords M, Fuller JL. 2010. Infanticide in Cercopithecus mitis stuhlmanni in the Kakamega Forest, Kenya: Variation in the occurrence of an adaptive behavior. Int J Primatol 31: 409-431.

Cowlishaw G. 1999. Ecological and social determinants of spacing behaviour in desert baboon groups. Behav Ecol Sociobiol 45: 67-77.

Crockett CM. 2003. Re-evaluating the sexual selection hypothesis for infanticide by Alouatta males. In Sexual selection and reproductive competition in primates: New perspectives and directions (ed. Jones CB), pp. 327-365. American Society of Primatologists, Norman, OK.

Crockett CM, Janson CH. 2000. Infanticide in red howlers: Female group size, male membership, and a possible link to folivory. In Infanticide by males and its implications (ed. van Schaik CP, Janson CH), pp. 75-98. Cambridge University Press, Cambridge.

Crofoot MC. 2007. Mating and feeding competition in white-faced capuchins (Cebus capucinus): The importance of short- and long-term strategies. Behaviour 144: 1473-1495.

Crook JR, Shields WM. 1985. Sexually selected infanticide by adult male barn swallows. Anim Behav 33: 754-761.

Curtin R, Dolhinow P. 1978. Primate social behavior in a changing world. Am Sci 66: 468-475.

Dahle B, Swenson JE. 2003. Seasonal range size in relation to reproductive strategies in brown bears Ursus arctos. J Anim Ecol 72: 660-667.

Daly M, Wilson M. 1984. A sociobiological analysis of human infanticide. In Infanticide: Comparative and evolutionary perspectives (ed. Hausfater G, Hrdy SB), pp. 487502. Aldine, New York.

Daly M, Wilson M. 1994. Stepparenthood and the evolved psychology of discriminative parental solicitude. In Infanticide and parental care (ed. Parmigiani S, vom Saal F), pp. 121-134. Harwood, Chur, Switzerland.

Davies G. 1987. Adult male replacement and group formation in Presbytis rubicunda. Folia Primatol 49: 111-114.

Delgado RA, van Schaik CP. 2000. The behavioral ecology and conservation of the orangutan (Pongo pygmaeus): A tale of two islands. Evol Anthropol 9: 201-218.

Delibes M, Blázquez MC, Delibes-Mateos M. 2012. Historical books in ethology: Sexual purpose used to explain two ancient documentations of infanticide by males. Ethol Ecol Evol 24: 294-300.

de Villiers DJ. 1986. Infanticide in the tree squirrel, Paraxerus cepapi. S Afr J Zool 21: 183-184.

de Waal FBM. 1997. Bonobo: The forgotten ape. University of California Press, Berkeley, CA.

Dolhinow P. 1977. Normal monkeys? Am Sci 65: 266.

Dudzinski KM, Gregg JD, Ribic CA, Kuczaj SA. 2009. A comparison of pectoral fin contact between two different wild dolphin populations. Behav Proc 80: 182-190.
Dugdale HL, Griffiths A, MacDonald DW. 2011. Polygynandrous and repeated mounting behaviour in European badgers, Meles meles. Anim Behav 82: 1287-1297.

Dunn DG, Barco SG, Pabst A, McLellan WA. 2002. Evidence for infanticide in bottlenose dolphins of the western north Atlantic. J Wildlife Dis 38: 505-510.

Ebensperger LA. 1998a. Strategies and counterstrategies to infanticide in mammals. Biol Rev Camb Philos Soc 73: 321-346.

Ebensperger LA. 1998b. The potential effects of protected nests and cage complexity on maternal aggression in house mice. Agg Behav 24: 385-396.

Ebensperger LA. 2001. No infanticide in the hystricognath rodent, Octodon degus: Does ecology play a role? Acta Ethologica 3: 89-93.

Ebensperger LA, Blumstein DT. 2007. Nonparental infanticide. In Rodent societies: An ecological and evolutionary perspective (ed. Wolff JO, Sherman PA), pp. 267-279. University of Chicago Press, Chicago.

Ebensperger LA, Botto-Mahan C, Tamarin RH. 2000. Nonparental infanticide in meadow voles, Microtus pennsylvanicus: The influence of nutritional benefits. Ethol Ecol Evol 12: 149-160.

Eggert A-K, Müller JK. 1997. Biparental care and social evolution in burying beetles: Lessons from the larder. In The evolution of social behavior in insects and arachnids (ed. Choe JC, Crespi BJ), pp. 216-236. Cambridge University Press, Cambridge.

Elwood RW, Kennedy HF. 1994. Selective allocation of parental and infanticidal responses in rodents: A review of mechanisms. In Infanticide and parental care (ed. Parmigiani S, vom Saal F), pp. 397-425. Harwood, Chur, Switzerland.

Elwood RW, Ostermeyer MC. 1984a. The effects of food deprivation, aggression, and isolation on infanticide in the male Mongolian gerbil. Agg Behav 10: 293-301.

Elwood RW, Ostermeyer MC. 1984b. Infanticide by male and female Mongolian gerbils: Ontogeny, causation, and function. In Infanticide: Comparative and evolutionary perspectives (ed. Hausfater G, Hrdy SB), pp. 367-386. Aldine, New York.

Elwood RW, Nesbitt AA, Kennedy HF. 1990. Maternal aggression in response to the risk of infanticide by male mice, Mus musculus. Anim Behav 40: 1080-1086.

Engh AL, Beehner JC, Bergman TJ, Whitten PL, Hoffmeier RR, Seyfarth RM, Cheney DL. 2006. Female hierarchy instability, male immigration and infanticide increase glucocorticoid levels in female chacma baboons. Anim Behav 71: 1227-1237.

Enstam KL, Isbell LA, de Maar TW. 2002. Male demography, female mating behavior, and infanticide in wild patas monkeys (Erythrocebus patas). Int J Primatol 23: 85-104.

Erez T, Schneider JM, Lubin Y. 2005. Is male cohabitation costly for females of the spider Stegodyphus lineatus (Eresidae)? Ethology 111: 693-704.

Fairbanks LA, McGuire MT. 1987. Mother-infant relationships in vervet monkeys: Response to new adult males. Int J Primatol 8: 351-366.

Fairgrieve C. 1995. Infanticide and infant eating in the blue monkey (Cercopithecus mitis stuhlmanni) in the Budongo Forest Reserve, Uganda. Folia Primatol 64: 69-72. 
R.A. Palombit

Fedigan LM, Carnegie SD, Jack KM. 2008. Predictors of reproductive success in female white-faced capuchins (Cebus capucinus). Am J Phys Anthropol 137: 82-90.

Feh C, Munkhtuya B. 2008. Male infanticide and paternity analyses in a socially natural herd of Przewalski's horses: Sexual selection? Behav Proc 78: 335-339.

Freed LA. 1986. Territory takeover and sexually selected infanticide in tropical house wrens. Behav Ecol Sociobiol 19: 197-206.

Freed LA. 1987. Prospective infanticide and protection of genetic paternity in tropical house wrens. Am Nat 130: 948-954.

Fruteau C, Range F, Noë R. 2010. Infanticide risk and infant defence in multi-male free-ranging sooty mangabeys, Cercocebus atys. Behav Proc 83: 113-118.

Fuentes A. 2000. Hylobatid communities: Changing views on pair bonding and social organization in Hominoids. Am J Phys Anthropol 43: 33-60.

Galat-Luong A, Galat G. 1979. Conséquences comportementales des perturbations sociales repetées sure une troupe de Mones de Lowe, Cercopithecus campbelli lowei, de Côte d'Ivoire [Behavioral consequences of repeated social disturbance in a group of Cercopithecus campbelli lowei monkeys in the Ivory Coast]. Terre et Vie 33: 4-57.

Glass GE, Holt R, Slade NA. 1985. Infanticide as an evolutionarily stable strategy. Anim Behav 33: 384-391.

Goodall J. 1986. The chimpanzees of Gombe: Patterns of behavior. Belknap, Cambridge, MA.

Goodall J. 1990. Through a window. Houghton Mifflin, Boston.

Gray ME. 2009. An infanticide attempt by a free-roaming feral stallion (Equus caballus). Biol Lett 5: 23-25.

Gray SM, Dill LM, McKinnon JS. 2007. Cuckoldry incites cannibalism: Male fish turn to cannibalism when perceived certainty of paternity decreases. Am Nat 169: 258-263.

Grinnell J, McComb K. 1996. Maternal grouping as a defense against infanticide by males: Evidence from field playback experiments on African lions. Behav Ecol 7: 55-59.

Gust D. 1994. Alpha-male sooty mangabeys differentiate between females' fertile and their postconception maximal swellings. Int J Primatol 15: 289-301.

Hamai M, Nishida T, Takasaki H, Turner LA. 1992. New records of within-group infanticide in wild chimpanzees. Primates 33: 151-162.

Hamilton WD. 1971. Geometry for the selfish herd. J Theor Biol 31: 295-311.

Harris TR, Monfort SL. 2003. Behavioral and endocrine dynamics associated with infanticide in a black and white colobus monkey (Colobus guereza). Am J Primatol 61: $135-142$.

Hausfater G, Hrdy SB. 1984. Infanticide: Comparative and evolutionary perspectives. Aldine, New York.

Heiming RS, Mönning A, Jansen F, Kloke V, Lesch K-P, Sachser N. 2013. To attack, or not to attack? The role of serotonin transporter genotype in the display of maternal aggression. Behav Brain Res 242: 135-141.

Heistermann M, Ziegler TE, van Schaik CP, Launhardt K, Winkler P, Hodges JK. 2001. Loss of oestrus, concealed ovulation and paternity confusion in free-ranging Hanuman langurs. Proc Roy Soc Lond B 268: 2445-2451.

Henzi SP, Clarke PMR, van Schaik CP, Pradhan GR, Barrett L. 2010. Infanticide and reproductive restraint in a polygynous social mammal. Proc Natl Acad Sci 107: 2130 2135.

Hiraiwa-Hasegawa M. 1988. Adaptive significance of infanticide in primates. Trends Ecol Evol 3: 102-105.

Hoesli T, Nikowitz T, Walzer C, Kaczensky P. 2009. Monitoring of agonistic behaviour and foal mortality in freeranging Przewalski's horse harems in the Mongolian Gobi. Equus, September, 113-138.

Hoogland JL. 1985. Infanticide in prarie dogs: Lactating females kill offspring of close kin. Science 230: 10371040.

Hoogland JL. 2001. Black-tailed, Gunninson's, and Utah prairie dogs reproduce slowly. J Mammal 82: 917-927.

Hoogland JL. 2007. Alarm calling, multiple mating, and infanticide among black-tailed, Gunnison's, and Utah prairie dogs. In Rodent societies: An ecological and evolutionary perspective (ed. Wolff JO, Sherman PA), pp. 438450. University of Chicago Press, Chicago.

Hrdy SB. 1974. Male-male competition and infanticide among the langurs (Presbytis entellus) of Abu, Rajasthan. Folia Primatol 22: 19-58.

Hrdy SB. 1977. The langurs of Abu: Female and male strategies of reproduction. Harvard University Press, Cambridge, MA.

Hrdy SB. 1979. Infanticide among animals: A review, classification, and examination of the implications for reproductive strategies of females. Ethol Sociobiol 1: 13-40.

Hrdy SB. 1981. The woman that never evolved. Harvard University Press, Cambridge, MA.

Hrdy SB, Hausfater G. 1984. Comparative and evolutionary perspectives on infanticide: Introduction and overview. In Infanticide: Comparative and evolutionary perspectives (ed. Hausfater G, Hrdy SB), pp. xiii-xxxv. Aldine, New York.

Ichino S. 2005. Attacks on a wild infant ring-tailed lemur (Lemur catta) by immigrant males at Berenty, Madagascar: Interpreting infanticide by males. Am J Primatol 67: 267-272.

Isbell LA, Cheney DL, Seyfarth RD. 2002. Why vervet monkeys (Cercopithecus aethiops) live in multimale groups. In The guenons: Diversity and adaptation in African monkeys (ed. Glenn ME, Cords M), pp. 173-187. Kluwer, New York.

Ishibashi Y, Saitoh T. 2008. Effect of local density of males on the occurrence of multimale mating in gray-sided voles (Myodes rufocanus). J Mammal 89: 388-397.

Izar P, Stone A, Carnegie S, Nakai ES. 2009. Sexual selection, female choice and mating systems. In South American primates: Comparative perspectives in the study of behavior, ecology, and conservation (ed. Garber PA, et al.), pp. 157-189. Springer, New York.

Jack KM, Fedigan LM. 2009. Female dispersal in a femalephilopatric species, Cebus capucinus. Behaviour 146: 471-497.

Jansen T, Forster P, Levine MA, Oelke H, Hurles M, Renfrew C, Weber J, Olek K. 2002. Mitochondrial DNA and the 
origins of the domestic horse. Proc Natl Acad Sci 99: 10905-10910.

Janson CH, Goldsmith ML. 1995. Predicting group size in primates: Foraging costs and predation risks. Behav Ecol 6: $326-336$.

Janson CH, van Schaik CP. 2000. The behavioral ecology of infanticide by males. In Infanticide by males and its implications (ed. van Schaik CP, Janson CH), pp. 469-494. Cambridge University Press, Cambridge.

Kappeler PM. 1997. Determinants of primate social organization: Comparative evidence and new insights from Malagasy lemurs. Biol Rev Camb Philos Soc 72: 111-151.

Kappeler PM. 2012. Mate choice. In The evolution of primate societies (ed. Mitani JC, et al.), pp. 367-386. University of Chicago Press, Chicago.

Kiyota M, Okamura H. 2005. Harassment, abduction, and mortality of pups by nonterritorial male northern fur seals. J Mammal 86: 1227-1236.

Korstjens A, Nijssen E, Noë R. 2005. Intergroup relationships in western black-and-white colobus, Colobus polykomos polykomos. Int J Primatol 26: 1267-1289.

Koskela E, Juutistenaho P, Mappes T, Oksanen T. 2000. Offspring defence in relation to litter size and age: Experiment in the bank vole Clethrionomys glareolus. Evol Ecol 14: 99-109.

Kunz TH, Ebensperger LA. 1999. Why does non-parental infanticide seem so rare in bats? Acta Chiropterol 1: 1729.

Lane JE, Boutin S, Gunn MR, Slate J, Coltman DW. 2008. Female multiple mating and paternity in free-ranging North American red squirrels. Anim Behav 75: $1927-$ 1937.

Le Boeuf BJ, Campagna C. 1994. Protection and abuse of young in pinnipeds. In Infanticide and parental care (ed. Parmigiani S, vom Saal F), pp. 257-276. Harwood, Chur, Switzerland.

Le Galliard J-F, Gundersen G, Andreassen HP, Stenseth NC. 2006. Natal dispersal, interactions among siblings and intrasexual competition. Behav Ecol 17: 733-740.

Lewinson R. 1998. Infanticide in the hippopotamus: Evidence for polygynous ungulates. Ethol Ecol Evol 10: $277-$ 286.

Lewis RJ. 2008. Social influences on group membership in Propithecus verreauxi verreauxi. Int J Primatol 29: 1249 1270.

Lonstein JS, Gammie SC. 2002. Sensory, hormonal, and neural control of maternal aggression in laboratory rodents. Neurosci Biobehav Rev 26: 869-838.

Lötter T, Pillay N. 2012. Social interactions associated with reproduction in the bushveld gerbil Gerbilliscus leucogaster. Acta Theriol 57: 29-39.

Loveridge AJ, Searle AW, Murindagomo F, MacDonald DW 2007. The impact of sport-hunting on the population dynamics of an African lion population in a protected area. Biol Conserv 134: 548-558.

Lukas D, Clutton-Brock TH. 2013. The evolution of social monogamy in mammals. Science 341: 526-530.

Maan ME, Taborsky M. 2008. Sexual conflict over breeding substrate causes female expulsion and offspring loss in a cichlid fish. Behav Ecol 19: 302-308.
Maestripieri D, Alleva E. 1990. Maternal aggression and litter size in the female house mouse. Ethology 84: 27-34.

Maestripieri D, Rossi-Arnaud C. 1991. Kinship does not affect litter defence in pairs of communally nesting female house mice. Agg Behav 17: 223-228.

Manning CJ, Dewsbury DA, Wakeland EK, Potts WK. 1995. Communal nesting and communal nesting in house mice, Mus musculus domesticus. Anim Behav 50: 741751.

Marsh CW. 1979. Female transference and mate choice among Tana River red colobus. Nature 281: 568-569.

Matsumoto-Oda A. 1999. Mahale chimpanzees: Grouping patterns and cycling females. Am J Primatol 47: 197-207.

McComb K, Pusey A, Packer C, Grinnell J. 1993. Female lions can identify potentially infanticidal males from their roars. Proc Roy Soc Lond B 252: 59-64.

McGuire B, Bemis WE. 2007. Parental care. In Rodent societies: An ecological and evolutionary perspective (ed. Wolff JO, Sherman PA), pp. 231-242. University of Chicago Press, Chicago.

McLean IG. 1982. The association of female kin in the Arctic ground squirrel Spermophilus parryii. Behav Ecol Sociobiol 10: 91-99.

McLean IG. 1983. Paternal behaviour and killing of young in arctic ground squirrels. Anim Behav 31: 32-44.

McLellan BN. 2005. Sexually selected infanticide in grizzly bears: The effects of hunting on cub survival. Ursus 16: $141-156$.

Mennella JA, Moltz H. 1988. Infanticide in rats: Male strategy and female counter-strategy. Physiol Behav 42: 19-28.

Miller SD, Sellers RA, Keay JA. 2003. Effects of hunting on brown bear cub survival and litter size in Alaska. Ursus 14: $130-152$.

Mitani JC, Watts DP, Amsler SJ. 2010. Lethal intergroup aggression leads to territorial expansion in wild chimpanzees. Cur Biol 20: R507-R508.

Mock DW. 1984. Infanticide, siblicide, and avian nestling mortality. In Infanticide: Comparative and evolutionary perspectives (ed. Hausfater G, Hrdy SB), pp. 3-30. Aldine, New York.

Møller AP. 1988. Infanticidal and anti-infanticidal strategies in the swallow Hirundo rustica. Behav Ecol Sociobiol 22: $365-371$.

Møller AP. 2004. Rapid temporal change in frequency of infanticide in a passerine bird associated with change in population density and body condition. Behav Ecol 15: $462-468$.

Morelli TL, King SJ, Pochron ST, Wright PC. 2009. The rules of disengagement: Takeovers, infanticide, and dispersal in a rainforest lemur, Propithecus edwardsi. Behaviour 146: $499-523$.

Moscovice LR, Di Fiore A, Crockford C, Kitchen DM, Wittig R, Seyfarth RM, Cheney DL. 2010. Hedging their bets? Male and female chacma baboons form friendships based on likelihood of paternity. Anim Behav 79: 1007-1015.

Müller JK, Eggert AK, Sakaluk SK. 1998. Carcass maintenance and biparental brood care in burying beetles: Are males redundant? Ecol Entomol 23: 195-200.

Myers K, Poole WE. 1961. A study of the biology of the wild rabbit, Orytolagus cuniculus (L.), in confined popula- 
R.A. Palombit

tions: II. The effects of season and population increase on behaviour. CSIRO Wildlife Res 6: 1-41.

Nunn CL. 1999. The evolution of exaggerated sexual swellings in primates and the graded-signal hypothesis. Anim Behav 58: 229-246.

O'Brien TG. 1991. Female-male social interactions in wedge-capped capuchin monkeys: Benefits and costs of group living. Anim Behav 41: 555-567.

Oleinchenko VY. 2012. Behavioral interactions of adult females of the common shrew (Sorex araneus) with conspecifics on familiar territory. Biol Bull 39: 351-359.

Opie C, Atkinson QD, Dunbar RIM, Shultz S. 2013. Male infanticide leads to social monogamy in primates. Proc Natl Acad Sci 110: 13328-13332.

Ostner J, Kappeler PM. 2004. Male life history and the unusual adult sex ratios of redfronted lemur, Eulemur fulvus rufus, groups. Anim Behav 67: 249-259.

Packer C, Pusey AE. 1983. Adaptations of female lions to infanticide by incoming males. Am Nat 121: 716-728.

Packer C, Herbst L, Pusey AE, Bygott JD, Hanby JP, Cairns SJ, Mulder MB. 1988. Reproductive success in lions. In Reproductive success: Studies of individual variation in contrasting breeding systems (ed. Clutton-Brock TH), pp. 363-383. University of Chicago Press, Chicago.

Packer C, Scheel D, Pusey AE. 1990. Why lions form groups: Food is not enough. Am Nat 136: 9-19.

Palanza P, Re L, Mainardi D, Brain PF, Parmigiani S. 1996 Male and female competitive strategies of wild house mice pairs (Mus musculus domesticus) confronted with intruders of different sex and age in artificial territories. Behaviour 133: 863-882.

Palombit RA. 1999. Infanticide and the evolution of pair bonds in nonhuman primates. Evol Anthropol 7: 117129.

Palombit RA. 2000. Infanticide and the evolution of malefemale bonds in animals. In Male infanticide and its im plications (ed. van Schaik CP, Janson CH), pp. 239-268. Cambridge University Press, Cambridge.

Palombit RA. 2003. Male infanticide in wild savanna baboons: Adaptive significance and intraspecific variation. In Sexual selection and reproductive competition in primates: New perspectives and directions (ed. Jones CB), pp. 364-411. American Society of Primatologists, Norman, OK.

Palombit RA. 2009. Friendships with males: A female counterstrategy to infanticide in the Okavango chacma baboons. In Sexual coercion in primates and humans (ed. Muller MN, Wrangham RW), pp. 377-409. Harvard University Press, Cambridge, MA.

Palombit RA. 2010. Conflict and bonding between the sexes. In Mind the gap: Tracing the origin of human universals (ed. Kappeler PM, Silk JB), pp. 53-84. Springer, Berlin.

Palombit RA. 2012. Infanticide: Male strategies and female counterstrategies. In The evolution of primate societies (ed. Mitani JC, et al.), pp. 432-468. University of Chicago Press, Chicago.

Palombit RA. Infanticide. In Encyclopedia of human sexuality (ed. Whelehan P, Bolin A). Wiley, Hoboken, NJ (in press).

Palombit RA. 2014. Sexual conflict in nonhuman primates. Adv Stud Behav 46: 191-280.
Palombit RA, Seyfarth RM, Cheney DL. 1997. The adaptive value of "friendships" to female baboons: Experimental and observational evidence. Anim Behav 54: 599-614.

Palombit RA, Cheney DL, Fischer J, Johnson S, Rendall D, Seyfarth RM, Silk JB. 2000. Male infanticide and defense of infants in wild chacma baboons. In Infanticide by males and its implications (ed. van Schaik CP, Janson CH), pp. 123-152. Cambridge University Press, Cambridge.

Palombit RA, Cheney DL, Seyfarth RM. 2001. Female-female competition for male "friends" in wild chacma baboons (Papio cynocephalus ursinus). Anim Behav 61: 1159-1171.

Parmigiani S. 1986. Rank order in pairs of communally nursing female mice (Mus musculus domesticus) and maternal aggression towards conspecific intruders of differing sex. Agg Behav 12: 377-386.

Parmigiani S, Brain PF, Mainardi D, Brunoni V. 1988a. Different patterns of biting attack generated when lactating female mice (Mus domesticus) encounter male and female conspecific intruders. J Comp Psychol 102: 287-293.

Parmigiani S, Sgoifo A, Mainardi D. 1988b. Parental aggression displayed by female mice in relation to the sex, reproductive status, and infanticidal potential of conspecific intruders. Monit Zool Ital 22: 193-201.

Parmigiani S, Palanza P, Brain PF. 1989. Intraspecific maternal aggression in the house mouse (Mus domesticus): A counterstrategy to infanticide by male? Ethol Ecol Evol 1: 341-352.

Parmigiani S, Palanza P, Mainardi M, Mainardi D. 1990. Fear and defensive components of maternal aggression in mice. In Fear and defense (ed. Brain PF, et al.), pp. 109126. Harwood, London.

Parmigiani S, Palanza P, Mainardi D, Brain PF. 1994. Infanticide and protection of young in house mice (Mus domesticus): Female and male strategies. In Infanticide and parental care (ed. Parmigiani S, vom Saal F), pp. 341363. Harwood, Chur, Switzerland.

Parmigiani S, Palanza P, Rodgers J, Ferrari PF. 1999. Selection, evolution of behavior and animal models in behavioral neuroscience. Neurosci Biobehav Rev 23: 957-970.

Patterson IAP, Reid RJ, Wilson B, Grellier K, Ross HM, Thompson PM. 1998. Evidence for infanticide in bottlenose dolphins: An explanation for violent interactions with harbour porpoises. Proc Roy Soc Lond B 265: 1167-1170.

Paul L, Kupferschmidt J. 1975. Killing of conspecific and mouse young by male rats. J Comp Physiol Psychol 88: 755-763.

Pavé R, Kowalewski M, Garber P, Zunino G, Fernandez V, Peker S. 2012. Infant mortality in black-and-gold howlers (Alouatta caraya) living in a flooded forest in northeastern Argentina. Int J Primatol 33: 937-957.

Pazol K. 2003. Mating in the Kakamega forest blue monkeys (Cercopithecus mitis): Does female sexual behavior function to manipulate paternity assessment? Behaviour 140: 473-499.

Pereira M. 1983. Abortion following the immigration of an adult male baboon (Papio cynocephalus). Am J Primatol 4: 93-98. 
Pereira ME, Weiss ML. 1991. Female mate choice, male migration, and the threat of infanticide in ringtailed lemurs. Behav Ecol Sociobiol 28: 141-152.

Perrigo G, Bryant WC, vom Saal FS. 1990. A unique neural timing system prevents male mice from harming their own offspring. Anim Behav 39: 535-539.

Perrigo G, Belvin L, vom Saal F. 1992. Time and sex in the male mouse: Temporal regulation of infanticide and parental behavior. Chronobiol Int 9: 421-433.

Pierotti R. 1991. Infanticide versus adoption: An intergenerational conflict. Am Nat 138: 1140-1158.

Pluháček J, Bartoš L. 2000. Male infanticide in captive plains zebra, Equus caballus. Anim Behav 59: 689-694.

Pluháček J, Bartoš L. 2005. Further evidence for male infanticide and feticide in captive zebra, Equus burchelli. Folia Zool 54: 258-262.

Pusey AE, Packer C. 1987. The evolution of sex-biased dispersal in lions. Behaviour 101: 275-310.

Pusey AE, Packer C. 1994a. Non-offspring nursing in social carnivores: Minimizing the costs. Behav Ecol 5: 362-374.

Pusey AE, Packer C. 1994b. Infanticide in lions: Consequences and counterstrategies. In Infanticide and parental care (ed. Parmigiani S, vom Saal F), pp. 277-299. Harwood, Chur, Switzerland.

Rajpurohit IS, Chhangani AK, Rajpurohit RS, Bhaker NR, Rajpurohit DS, Sharma G. 2008. Recent observations on resident male change followed by infanticide in Hanuman langurs (Semnopithecus entellus) around Jodhpur. Primate Rep 75: 33-40.

Ramírez-Llorens P, Di Bitetti MS, Baldovino MC, Janson CH. 2008. Infanticide in black capuchin monkeys (Cebus apella nigritus) in Iguazú National Park, Argentina. Am J Primatol 70: 473-484.

Rees A. 2009. The infanticide controversy. University of Chicago Press, Chicago.

Rémy A, Odden M, Richard M, Stene MT, Le Galliard J-F, Andreassen HP. 2013. Food distribution influences social organization and population growth in a small rodent. Behav Ecol 24: 832-841.

Richard AF, Rakotomanga P, Schwartz M. 1993. Dispersal by Propithecus verreauxi at Beza Mahafaly, Madagascar: 1984-1991. Am J Primatol 30: 1-20.

Rijksen HD. 1981. Infant killing: A possible consequence of a disputed leader role. Behaviour 78: 138-167.

Robbins AM, Stoinski T, Fawcett K, Robbins M. 2009a. Socioecological influences on the dispersal of female mountain gorillas-Evidence of a second folivore paradox. Behav Ecol Sociobiol 63: 477-489.

Robbins AM, Stoinski T, Fawcett K, Robbins MM. 2009b. Leave or conceive: Natal dispersal and philopatry of female mountain gorillas in the Virunga volcano region. Anim Behav 77: 831-838.

Roberts EK, Lu A, Bergman TJ, Beehner JC. 2012. A Bruce effect in wild geladas. Science 335: 1222-1225.

Robertson RJ. 1990. Tactics and counter-tactics of sexually selected infanticide in tree swallows. In Population biology of passerine birds: An integrated approach (ed. Blondel J, et al.), pp. 381-390. Springer, Berlin.
Robertson IC. 1993. Nest intrusions, infanticide, and parental care in the burying beetle, Nicrophorus orbicollis (Coleoptera, Silphidae). J Zool 231: 583-593.

Robertson RJ, Stutchbury BJ. 1988. Experimental evidence for sexually selected infanticide in tree swallows. Anim Behav 36: 749-753.

Rohwer S. 1986. Selection for adoption versus infanticide by replacement mates in birds. Cur Ornithol 3: 353-395.

Rudran R. 1973a. The reproductive cycles of two subspecies of purple-faced langurs (Presbytis senex) with relation to enviornmental factors. Folia Primatol 19: 41-60.

Rudran R. 1973b. Adult male replacement in one-male troops of purple faced langurs (Presbytis senex senex) and its effect on population structure. Folia Primatol 19: $166-192$.

Sakura O. 1994. Factors affecting party size and composition of chimpanzees (Pan troglodytes verus) Bossou, Guinea. Int J Primatol 15: 167-183.

Schneider JM, Lubin Y. 1997. Infanticide by males in a spider with suicidal maternal care, Stegodyphus lineatus (Eresidae). Anim Behav 54: 305-312.

Schülke O. 2005. Evolution of pair-living in Phaner furcifer. Int J Primatol 26: 903-919.

Sherman PW. 1981. Reproductive competition and infanticide in Belding's ground squirrels and other animals. In Natural selection and social behavior (ed. Alexander RD, Tinkle DW), pp. 311-331. Chiron, New York.

Sicotte P, Teichroeb J, Saj T. 2007. Aspects of male competition in Colobus vellerosus: Preliminary data on male and female loud calling, and infant deaths after a takeover. Int J Primatol 28: 627-636.

Singh M, Kumara HN, Ananda KM, Singh M, Cooper M. 2006. Male influx, infanticide, and female transfer in Macaca radiata. Int J Primatol 27: 515-528.

Solomon NG, Keane B. 2007. Reproductive strategies in female rodents. In Rodent societies: An ecological and evolutionary perspective (ed. Wolff JO, Sherman PA), pp. 42 56. University of Chicago Press, Chicago.

Soltis J, Thomsen R, Matusabayshi K, Takenaka O. 2000. Infanticide by resident males and female counter-strategies in wild Japanese macaques (Macaca fuscata). Behav Ecol Sociobiol 48: 195-202.

Sommer V. 1994. Infanticide among the langurs of Jodhpur: Testing the sexual selection hypothesis with a long-term record. In Infanticide and parental care (ed. Parmigiani S, vom Saal F), pp. 155-198. Harwood, Chur, Switzerland.

Sommer S. 1997. Monogamy in Hypogeomys antimena, an endemic rodent of the deciduous dry forest in western Madagascar. J Zool 241: 301-314.

Starin ED. 1994. Philopatry and affiliation among red colobus. Behaviour 130: 253-270.

Steenbeek R. 1999a. Tenure related changes in wild Thomas's langurs: I. Between-group interactions. Behaviour 136: 595-625.

Steenbeek R. 1999b. "Female choice and male coercion in wild Thomas's langurs." PhD dissertation, Utrecht University, Netherlands.

Steenbeek R. 2000. Infanticide by males and female choice in wild Thomas's langurs. In Infanticide by males and its implications (ed. van Schaik CP, Janson CH), pp. 153177. Cambridge University Press, Cambridge. 
R.A. Palombit

Sterck EHM. 1997. Determinants of female dispersal in Thomas langurs. Am J Primatol 42: 179-198.

Sterck EHM. 1998. Variation in langur social organization in relation to the socioecological model, human habitat alteration, and phylogenetic constraints. Primates 40: 199213.

Sterck EHM, Watts DP, van Schaik CP. 1997. The evolution of female social relationships in nonhuman primates. Behav Ecol Sociobiol 41: 291-309.

Stokes EJ. 2004. Within-group social relationships among females and adult males in wild western lowland gorillas (Gorilla gorilla gorilla). Am J Primatol 64: 233-246.

Stokes E, Parnell RJ, Olejniczak C. 2003. Female dispersal and reproductive success in wild western lowland gorillas. Behav Ecol Sociobiol 54: 329-339.

Struhsaker TT, Leland L. 1985. Infanticide in a patrilineal society of red colobus monkeys. Z Tierpsychol 69: 89132.

Svare B, Bartke A. 1978. Food deprivation induces conspecific pup-killing in mice. Agg Behav 4: 253-261.

Swedell L, Saunders J. 2006. Infant mortality, paternity certainty, and female reproductive strategies in hamadryas baboons. In Reproduction and fitness in baboons: Behavioral, ecological, and life history perspectives (ed. Swedell L, Leigh SR), pp. 19-51. Springer, New York.

Swenson JE, Brunberg S, Segerström P. 2001. Factors associated with loss of brown bear cubs in Sweden. Ursus 12: 69-80.

Takahata Y, Sprague DS, Suzuki S, Okayasu N. 1994. Female competition, co-existence, and the mating structure of wild Japanese macaques on Yakushima Island, Japan. Physiol Ecol 29: 163-179.

Teichroeb JA, Sicotte P. 2008. Infanticide in ursine colobus monkeys (Colobus vellerosus) in Ghana: New cases and a test of the existing hypotheses. Behaviour 145: 727-755.

Teichroeb JA, Wikberg EC, Sicotte P. 2009. Female dispersa patterns in six groups of ursine colobus (Colobus vellerosus): Infanticide avoidance is important. Behaviour 146: $551-582$.

Thalmann U. 2001. Food resource characteristics in two nocturnal lemurs with different social behavior: Avahi occidentalis and Lepilemur edwardsi. Int J Primatol 22: 287-324.

Thonhauser KE, Raveh S, Hettyey A, Beissmann H, Penn DJ. 2013. Why do female mice mate with multiple males? Behav Ecol Sociobiol 67: 1961-1970.

Treves A. 2001. Reproductive consequences of variation in the composition of howler monkey (Alouatta spp.) groups. Behav Ecol Sociobiol 50: 61-71.

Treves A, Chapman CA. 1996. Conspecific threat, predation avoidance, and resource defense: Implications for grouping in langurs. Behav Ecol Sociobiol 39: 43-53.

Trivers RL. 1972. Parental investment and sexual selection. In Sexual selection and the descent of man, 1871-1971 (ed. Campbell B), pp. 136-179. Aldine, Chicago.

Trumbo ST. 1990a. Reproductive benefits of infanticide in a biparental burying beetle Nicrophorus orbicollis. Behav Ecol Sociobiol 27: 269-273.

Trumbo ST. 1990b. Interference competition among burying beetles (Silphidae, Nicrophorus). Ecol Entomol 15: $347-355$.
Trumbo ST. 1991. Reproductive benefits and the duration of paternal care in a biparental burying beetle, Necrophorus orbicollis. Behaviour 117: 82-115.

Trumbo ST. 2007. Defending young biparentally: Female risk-taking with and without a male in the burying beetle, Nicrophorus pustulatus. Behav Ecol Sociobiol 61: 1717-1723.

Trumbo ST, Valletta RC. 2007. The costs of confronting infanticidal intruders in a burying beetle. Ethology 113: 386-393.

van Noordwijk MA, van Schaik CP. 2000. Reproductive patterns in eutherian mammals: Adaptations against infanticide. In Infanticide by males and its implications (ed. van Schaik CP, Janson CH), pp. 322-360. Cambridge University Press, Cambridge.

van Schaik CP. 2000a. Infanticide by male primates: The sexual selection hypothesis revisited. In Infanticide by males and its implications (ed. van Schaik CP, Janson $\mathrm{CH}$, pp. 27-60. Cambridge University Press, Cambridge.

van Schaik CP. 2000b. Vulnerability to infanticide by males: Patterns among mammals. In Infanticide by males and its implications (ed. van Schaik CP, Janson CH), pp. 61-71. Cambridge University Press, Cambridge.

van Schaik CP, Dunbar RIM. 1990. The evolution of monogamy in large primates: A new hypothesis and some crucial tests. Behaviour 115: 30-62.

van Schaik CP, Janson CH (eds.). 2000. Infanticide by males and its implications. Cambridge University Press, Cambridge.

van Schaik CP, Hodges JK, Nunn CL. 2000. Paternity confusion and the ovarian cycles of female primates. In Infanticide by males and its implications (ed. van Schaik CP, Janson CH), pp. 361-387. Cambridge University Press, Cambridge.

Veiga JP. 1993. Prospective infanticide and ovulation retardation in free-living sparrows. Anim Behav 45: 43-46.

Veiga JP. 2000. Infanticide by male birds. In Infanticide by males and its implications (ed. van Schaik CP, Janson CH), pp. 198-220. Cambridge University Press, Cambridge.

Vestal BM. 1991. Infanticide and cannibalism by male thirteen-lined ground squirrels. Anim Behav 41: 1103-1104.

vom Saal FS. 1985. Time-contingent change in infanticide and parental behavior induced by ejaculation in male mice. Physiol Behav 34: 7-15.

vom Saal FS, Howard LS. 1982. The regulation of infanticide and parental behavior: Implications for reproductive success in male mice. Science 215: 1270-1272.

Watts DP. 1989. Infanticide in mountain gorillas: New cases and a reconsideration of the evidence. Ethology 81: 1-18.

Watts DP, Mitani JC, Sherrow HM. 2002. New cases of intercommunity infanticide by male chimpanzees at Ngogo, Kibale National Park, Uganda. Primates 43: 263-270.

Weber EM, Olsson IAS. 2008. Maternal behaviour in Mus musculus sp.: An ethological review. Appl Anim Behav Sci 114: $1-22$.

Weingrill T. 2000. Infanticide and the value of male-female relationships in mountain chacma baboons (Papio cynocephalus ursinus). Behaviour 137: 337-359. 
Wielgus RB, Bunnell FL. 2000. Possible negative effects of adult male mortality on female grizzly bear reproduction. Biol Conserv 93: 145-154.

Wielgus RB, Morrison DE, Cooley HS, Maletzke B. 2013. Effects of male trophy hunting on female carnivore population growth and persistence. Biol Conserv 167: 69-75.

Williams GC. 1966. Adaptation and natural selection. Princeton University Press, Princeton, NJ.

Williams JM, Pusey AE, Carlis JV, Farm BP, Goodall J. 2002. Female competition and male territorial behaviour influence female chimpanzees' ranging patterns. Anim Behav 63: $347-360$.

Williams JM, Oehlert GW, Carlis JV, Pusey AE. 2004. Why do male chimpanzees defend a group range? Anim Behav 68: $523-532$.

Williams JM, Lonsdorf EV, Wilson ML, Schumacher-Stankey J, Goodall J, Pusey AE. 2008. Causes of death in the Kasekela chimpanzees of Gombe National Park, Tanzania. Am J Primatol 70: 766-777.

Wolff JO, Cicirello DM. 1991. Comparative paternal and infanticidal behavior of white-footed mice (Peromyscus leucopus noveoboracensis) and deermice (P. maniculatus nubiterrae). Behav Ecol 2: 38-45.

Wolff JO, MacDonald DW. 2004. Promiscuous females protect their offspring. Trends Ecol Evol 19: 127-134.

Wolff JO, Peterson JA. 1998. An offspring-defense hypothesis for territoriality in female mammals. Ethol Ecol Evol 10: $227-239$.

Wrangham RW. 1980. An ecological model of female-bonded primate groups. Behaviour 75: 262-299.
Wrangham RW, Smuts BB. 1980. Sex differences in the behavioural ecology of chimpanzees in the Gombe National Park. J Reprod Fertil Suppl 28: 13-31.

Wright PC. 1995. Demography and life history of free-ranging Propithecus diadema edwardsi in Ranomafana National Park, Madagascar. Int J Primatol 16: 835-854.

Yamada K, Nakamichi M. 2006. A fatal attack on an unweaned infant by a non-resident male in a free-ranging group of Japanese macaques (Macaca fuscata) at Katsuyama. Primates 47: 165-169.

Yamagiwa J, Kahekwa J, Basabose AK. 2009. Infanticide and social flexibility in the genus Gorilla. Primates 50: 293303.

Yamaguchi N, Dugdale H, MacDonald DW. 2006. Female receptivity, embryonic diapause, and superfetation in the European badger (Meles meles): Implications for the reproductive tactics of males and females. Q Rev Biol 81: $33-48$.

Yamamura N, Hasegawa T, Ito Y. 1990. Why mothers do not resist infanticide: A cost-benefit genetic model. Evolution 44: 1346-1357.

Ylönen H, Koskela E, Mappes T. 1997. Infanticide in the bank vole (Clethrionomys glareolus): Occurrence and the effect of familiarity on female infanticide. Ann Zoo Fenn 34: 259-266.

Zedrosser A, Dahle B, Støen O-G, Swenson J. 2009. The effects of primiparity on reproductive performance in the brown bear. Oecologia 160: 847-854.

Zinner D, Deschner T. 2000. Sexual swellings in female hamadryas baboons after male take-overs: "Deceptive" swellings as a possible female counter-strategy against infanticide. Am J Primatol 52: 157-168. 


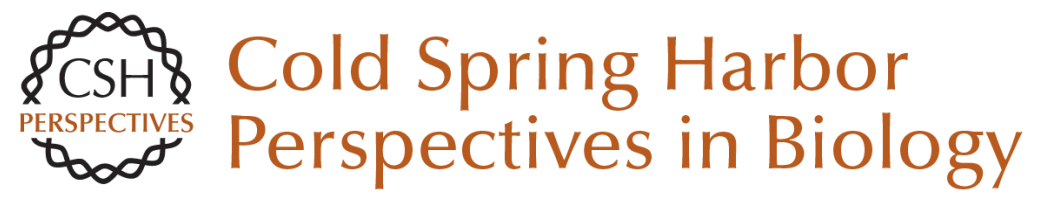

\title{
Infanticide as Sexual Conflict: Coevolution of Male Strategies and Female Counterstrategies
}

\author{
Ryne A. Palombit
}

Cold Spring Harb Perspect Biol 2015; doi: 10.1101/cshperspect.a017640 originally published online May 18,2015

\section{Subject Collection The Genetics and Biology of Sexual Conflict}

Mechanisms and Evidence of Genital

Coevolution: The Roles of Natural Selection, Mate

Choice, and Sexual Conflict

Patricia L.R. Brennan and Richard O. Prum

The Evolution of Sexually Antagonistic

Phenotypes

Jennifer C. Perry and Locke Rowe

Reproductive Parasitism: Maternally Inherited

Symbionts in a Biparental World

Gregory D.D. Hurst and Crystal L. Frost

Sex-Biased Gene Expression and Sexual Conflict throughout Development

Fiona C. Ingleby, llona Flis and Edward H. Morrow

Human Homosexuality: A Paradigmatic Arena for

Sexually Antagonistic Selection?

Andrea Camperio Ciani, Umberto Battaglia and Giovanni Zanzotto

Sexual Conflict Arising from Extrapair Matings in Birds

Alexis S. Chaine, Robert Montgomerie and Bruce E. Lyon

Sexual Conflict and Seminal Fluid Proteins: A Dynamic Landscape of Sexual Interactions

Laura K. Sirot, Alex Wong, Tracey Chapman, et al.
Infanticide as Sexual Conflict: Coevolution of

Male Strategies and Female Counterstrategies Ryne A. Palombit

Copulatory Wounding and Traumatic

Insemination

Klaus Reinhardt, Nils Anthes and Rolanda Lange

Sexual Conflict in Hermaphrodites

Lukas Schärer, Tim Janicke and Steven A. Ramm

Sexual Conflict and Sperm Competition

Dominic A. Edward, Paula Stockley and David J. Hosken

Sexually Antagonistic Zygotic Drive: A New Form of Genetic Conflict between the Sex

Chromosomes Urban Friberg and William R. Rice

Sex Chromosome Drive

Quentin Helleu, Pierre R. Gérard and Catherine Montchamp-Moreau

Is Sexual Conflict an "Engine of Speciation"? Sergey Gavrilets

For additional articles in this collection, see http://cshperspectives.cshlp.org/cgi/collection/

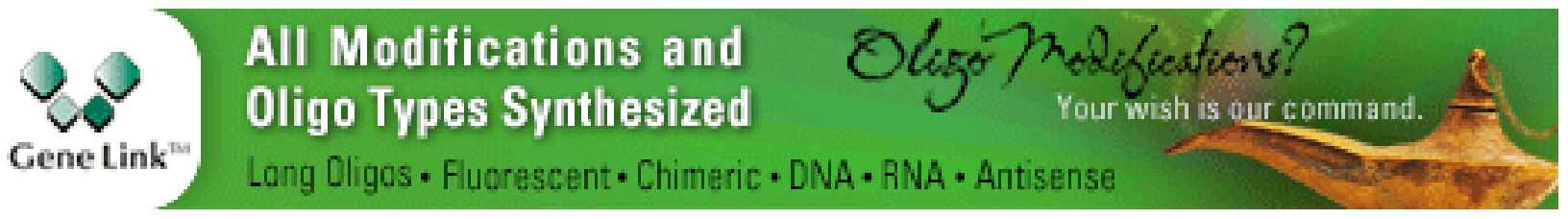


Conflict on the Sex Chromosomes: Cause, Effect, and Complexity

Judith E. Mank, David J. Hosken and Nina Wedell
Sexual Cannibalism as a Manifestation of Sexual

Conflict

Jutta M. Schneider

For additional articles in this collection, see http://cshperspectives.cshlp.org/cgi/collection/

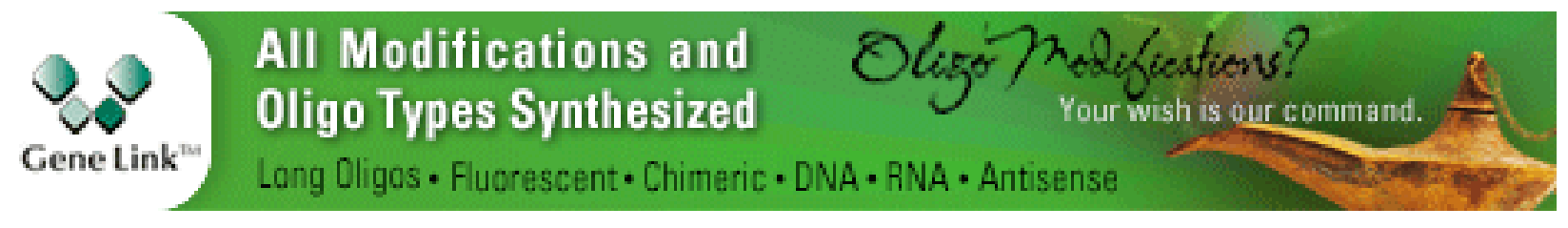

Copyright @ 2015 Cold Spring Harbor Laboratory Press; all rights reserved 